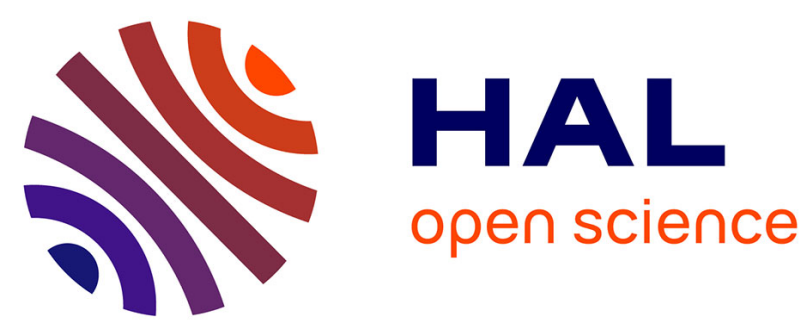

\title{
Quaterthiophenes with Terminal Indeno[1,2-b]thiophene Units as p-Type Organic Semiconductors
}

Laurent Pouchain, Olivier Alévêque, Yohann Nicolas, Agathe Oger, Charles-Henri Le Regent, Magali Allain, Philippe Blanchard, Jean Roncali

\section{- To cite this version:}

Laurent Pouchain, Olivier Alévêque, Yohann Nicolas, Agathe Oger, Charles-Henri Le Regent, et al.. Quaterthiophenes with Terminal Indeno[1,2-b]thiophene Units as p-Type Organic Semiconductors. Journal of Organic Chemistry, 2009, 74 (3), pp.1054 - 1064. 10.1021/jo802028n . hal-03343391

\section{HAL Id: hal-03343391 \\ https://univ-angers.hal.science/hal-03343391}

Submitted on 14 Sep 2021

HAL is a multi-disciplinary open access archive for the deposit and dissemination of scientific research documents, whether they are published or not. The documents may come from teaching and research institutions in France or abroad, or from public or private research centers.
L'archive ouverte pluridisciplinaire HAL, est destinée au dépôt et à la diffusion de documents scientifiques de niveau recherche, publiés ou non, émanant des établissements d'enseignement et de recherche français ou étrangers, des laboratoires publics ou privés. 


\section{The Journal of Organic Chemistry}

Subscriber access provided by UNIV D'ANGERS

\section{Article}

\section{Quaterthiophenes with Terminal Indeno[1,2-b]thiophene Units as $p$-Type Organic Semiconductors}

Laurent Pouchain, Olivier Ale\#ve\#que, Yohann Nicolas, Agathe Oger, Charles-Henri Le Re\#gent, Magali Allain, Philippe Blanchard, and Jean Roncali J. Org. Chem., 2009, 74 (3), 1054-1064• DOI: 10.1021/jo802028n • Publication Date (Web): 12 January 2009

Downloaded from http://pubs.acs.org on February 13, 2009
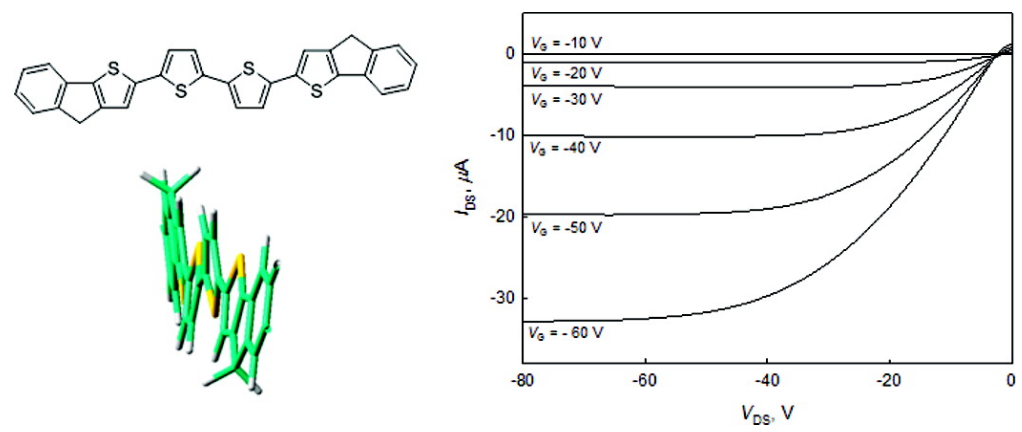

\section{More About This Article}

Additional resources and features associated with this article are available within the HTML version:

- Supporting Information

- Links to the 1 articles that cite this article, as of the time of this article download

- $\quad$ Access to high resolution figures

- $\quad$ Links to articles and content related to this article

- Copyright permission to reproduce figures and/or text from this article

\section{View the Full Text HTML}




\title{
Quaterthiophenes with Terminal Indeno[1,2-b]thiophene Units as $p$-Type Organic Semiconductors
}

\author{
Laurent Pouchain, Olivier Alévêque, Yohann Nicolas, ${ }^{\dagger}$ Agathe Oger, Charles-Henri Le Régent, \\ Magali Allain, Philippe Blanchard,* and Jean Roncali \\ University of Angers, CNRS, CIMA, Linear Conjugated Systems Group, \\ 2 Boulevard Lavoisier, 49045 Angers, France \\ Philippe.Blanchard@univ-angers.fr \\ Received September 12, 2008
}
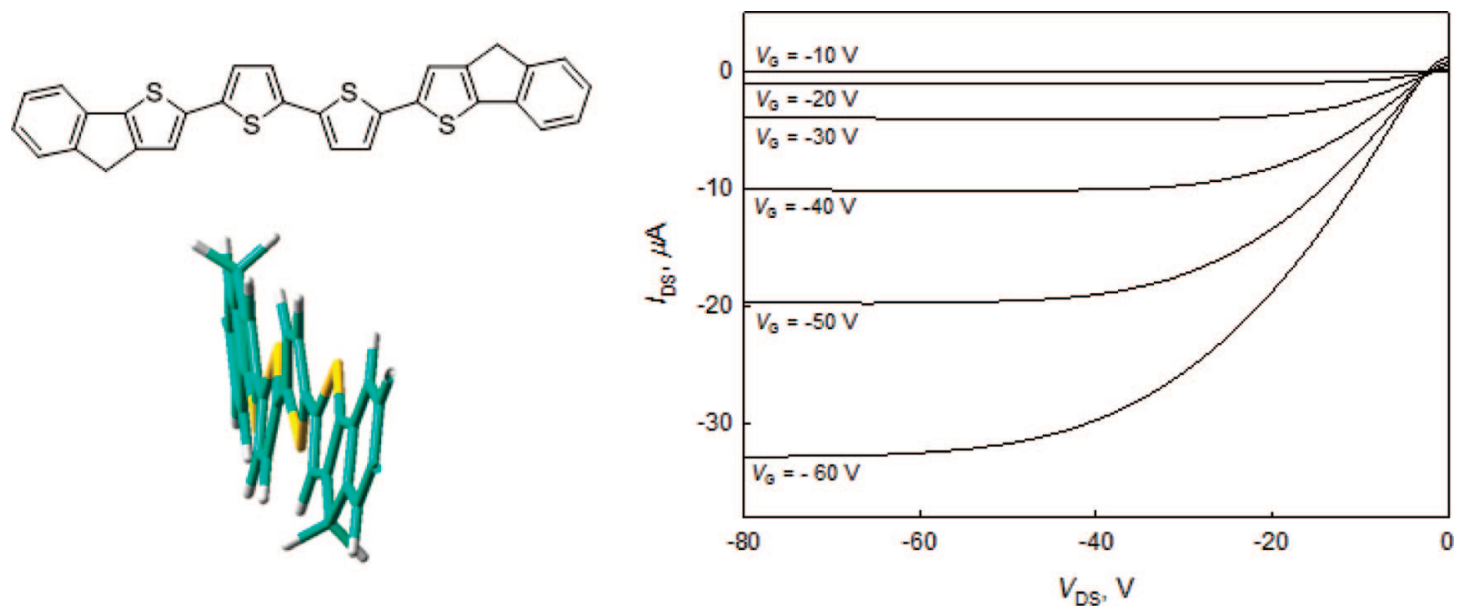

Quaterthiophenes 4T, Oct-4T, and Tol-4T based on a central 2,2'-bithiophene core $\alpha, \omega$-terminated with 4,4-unsubstituted and 4,4-disubstituted $n$-octyl or $p$-tolyl indeno[1,2-b]thiophene have been synthesized by Stille or Miyaura-Suzuki couplings. Compound $4 \mathbf{T}$ was also synthesized by an alternative route involving a soluble precursor bearing solubilizing trimethylsilyl groups which have been eliminated in the last step. The electronic properties of the compounds have been analyzed by cyclic voltammetry, UV-vis absorption and fluorescence emission spectroscopy. Thermal evaporation of $\mathbf{4 T}$ and Oct-4T leads to crystalline thin films and UV-vis absorption and X-ray diffraction data for these films suggest that the molecules adopt a quasi-vertical orientation onto the substrate. Strong $\pi-\pi$ intermolecular interactions have been observed for 4T but not for molecules Oct-4T due to the presence of $n$-octyl chains. Sublimed thin films of Tol-4T show an amorphous character. The characterization of field-effect transistors fabricated from these three materials gave a hole-mobility of $2.2 \times 10^{-2} \mathrm{~cm}^{2} \mathrm{~V}^{-1} \mathrm{~s}^{-1}$ with an on/off ratio of $2.2 \times 10^{4}$ for $\mathbf{4 T}$ while no field-effect was observed for Oct-4T and Tol-4T.

\section{Introduction}

Organic field-effect transistors (OFETs) are intensively investigated in view of their potential applications in active matrix displays, RFID, and sensors. ${ }^{1-9}$ In this context, materials

$\uparrow$ Permanent address: University of Bordeaux 1, CNRS, ISM, 351 cours de la libération, 33405 Talence, France.

(1) Dimitrakopoulos, C. D.; Malenfant, P. R. L. Adv. Mater. 2002, 14, 99117.

(2) Newman, C. R.; Frisbie, C. D.; da Silva, D. A.; Brédas, J. L.; Ewbank, P. C.; Mann, K. R. Chem. Mater. 2004, 16, 4436-4451.

(3) Ling, M. M.; Bao, Z. Chem. Mater. 2004, 16, 4824-4840. derived from linear $\pi$-conjugated systems are a focus of intense research effort. ${ }^{5,10-16}$ Whereas acenes ${ }^{1,10,17,18}$ and thiophene $e^{1,19-22}$

(4) Bao, Z.; Locklin, J. J. Organic Field-Effect Transistors; CRC Press: Boca Raton, FL, 2007.

(5) Zaumseil, J.; Sirringhaus, H. Chem. Rev. 2007, 107, 1296-1323.

(6) (a) Crone, B.; Dodabalapur, A.; Gelperin, A.; Torsi, L.; Katz, H. E.; Lovinger, A. J.; Bao, Z. Appl. Phys. Lett. 2001, 78, 2229-2231. (b) Someya, T.; Katz, H. E.; Gelperin, A.; Lovinger, A. J.; Dodabalapur, A. Appl. Phys. Lett. 2002, 81, 3079-3081

(7) Loo, Y.-L.; McCulloch, I. MRS Bull. 2008, 33, 653-662.

(8) Sirringhaus, H.; Ando, M. MRS Bull. 2008, 33, 676-682.

(9) Someya, T.; Pal, B.; Huang, J.; Katz, H. E. MRS Bull. 2008, 33, 690696.

10.1021/jo802028n CCC: \$40.75 — 2009 American Chemical Society Published on Web 01/12/2009 
oligomers still represent some of the most widely investigated classes of organic semiconductors, recent years have witnessed the emergence of various classes of hybrid conjugated systems. $^{20,23}$

Thiophene-phenylene hybrid oligomers have attracted special interest due to a combination of high hole-mobility and synthetic

(10) Anthony, J. E. Chem. Rev. 2006, 106, 5028-5048.

(11) Murphy, A. R.; Fréchet, J. M. J. Chem. Rev. 2007, 107, 1066-1096.

(12) Shirota, Y.; Kageyama, H. Chem. Rev. 2007, 107, 953-1010.

(13) Reese, C.; Bao, Z. Mater. Today 2007, 10, 20-27.

(14) Facchetti, A. Mater. Today 2007, 10, 28-37.

(15) Blanchard, P.; Leriche, P.; Frère, P.; Roncali, J. in Handbook of Conducting Polymers, 3rd ed.; Skotheim, T. A., Reynolds, J. R., Eds.; CRC Press: Boca Raton, 2007; Chapter 13.

(16) Allard, S.; Forster, M.; Souharce, B.; Thiem, H.; Scherf, U. Angew. Chem., Int. Ed. 2008, 47, 4070-4098.

(17) (a) Bendikov, M.; Wudl, F.; Perepichka, D. F. Chem. Rev. 2004, 104 4891-4946. (b) Ito, K.; Suzuki, T.; Sakamoto, Y.; Kubota, D.; Inoue, Y.; Sato, F.; Tokito, S. Angew. Chem., Int. Ed. 2003, 42, 1159-1162. (c) Meng, H Bendikov, M.; Mitchell, G.; Helgeson, R.; Wudl, F.; Bao, Z.; Siegriest, T.; Kloc, C.; Chen, C.-H. Adv. Mater. 2003, 15, 1090-1093. (d) Moon, H.; Zeis, R.; Borkent, E.-J.; Besnard, C.; Lovinger, A. J.; Siegriest, T.; Kloc, C.; Bao, Z J. Am. Chem. Soc. 2004, 126, 15322-15323. (e) Briseno, A. L.; Miao, Q.; Ling, M.-M.; Reese, C.; Meng, H.; Bao, Z.; Wudl, F. J. Am. Chem. Soc. 2006, 128, $15576-15577$.

(18) Li, Y; Wu, Y; Liu, P.; Prostran, Z; Gardner, S.; Ong, B. S. Chem Mater. 2007, 19, 418-423.

(19) Garnier, F. Acc. Chem. Res. 1999, 32, 209-215

(20) Katz, H. E.; Bao, Z; Gilat, S. Acc. Chem. Res. 2001, 34, 359-369.

(21) (a) Garnier, F.; Yassar, A.; Hajlaoui, R.; Horowitz, G.; Deloffre, F.; Servet, B.; Ries, S.; Alnot, P. J. Am. Chem. Soc. 1993, 115, 8716-8721. (b) Katz, H. E.; Torsi, L.; Dodabalapur, A. Chem. Mater. 1995, 7, 2235-2237. (c) Yassar, A.; Horowitz, G.; Valat, P.; Wintgens, V.; Hmyene, M.; Deloffre, F Srivastava, P.; Lang, P.; Garnier, F. J. Phys. Chem. 1995, 99, 9155-9159. (d) Katz, H. E.; Lovinger, A. J.; Laquindanum, J. G. Chem. Mater. 1998, 10, 457459. (e) Barbarella, G.; Zambianchi, M.; Antolini, L.; Ostoja, P.; Maccagnani, P.; Bongini, A.; Marseglia, E. A.; Tedesco, E.; Gigli, G.; Cingolani, R. J. Am. Chem. Soc. 1999, 121, 8920-8926. (f) Halik, M.; Klauk, H.; Zshieschang, U.; Schmid, G.; Ponomarenko, S.; Kirchmeyer, S.; Weber, W. Adv. Mater. 2003 $15,917-922$.

(22) Videlot, C.; Ackermann, J.; Blanchard, P.; Raimundo, J.-M.; Frère, P.; Allain, M.; de Bettignies, R.; Levillain, E.; Roncali, J. Adv. Mater. 2003, 15 306-310.

(23) (a) Laquindanum, J. G.; Katz, H. E.; Lovinger, A. J. J. Am. Chem. Soc. 1998, 120, 664-672. (b) Kelley, T. M.; Baude, P. F.; Gerlach, C.; Ender, D. E.; Muyres, D.; Haase, M. A.; Vogel, D. E.; Theiss, S. D. Chem. Mater. 2004, 16, 4413-4422. (c) Takimiya, K.; Kunugi, Y.; Toyoshima, Y.; Otsubo, T. J. Am. Chem. Soc. 2005, 127, 3605-3612. (d) Meng, H.; Sun, F.; Goldfinger, M. B.; Jaycox, G. D.; Li, Z.; Marshall, W. J.; Blackman, G. S. J. Am. Chem. Soc. 2005 127, 2406-2407. (e) Merlo, J. A.; Newman, C. R.; Gerlach, C. P.; Kelley, T. W.; Muyres, D. V.; Fritz, S. E.; Toney, M. F.; Frisbie, C. D. J. Am. Chem. Soc. 2005, 127, 3997-4009. (f) Payne, M. M.; Parkin, S. R.; Anthony, J. E.; Kuo, C.-C.; Jackson, T. N. J. Am. Chem. Soc. 2005, 127, 4986-4987. (g) Ando, S.; Nishida, J.-I.; Fujiwara, E.; Tada, H.; Inoue, Y.; Tokito, S.; Yamashita, Y. Chem Mater. 2005, 17, 1261-1264. (h) Nicolas, Y.; Blanchard, P.; Roncali, J.; Allain, M.; Mercier, N.; Deman, A.-L.; Tardy, J. Org. Lett. 2005, 7, 3513-3516. (i) Dickey, K. C.; Anthony, J. E.; Loo, Y.-L. Adv. Mater. 2006, 18, 1721-1726. (j) Valiyev, F.; Hu, W.-S.; Chen, H.-Y.; Kuo, M.-Y.; Chao, I.; Tao, Y.-T. Chem. Mater. 2007, 19, 3018-3026. (k) Yuan, Q.; Mannsfeld, S. C. B.; Tang, M. L. Toney, M. F.; Lüning, J.; Bao, Z. J. Am. Chem. Soc. 2008, 130, 3502-3508. (1) Tang, M. L.; Reichardt, A. D.; Miyaki, N.; Stoltenberg, R. M.; Bao, Z. J. Am. Chem. Soc. 2008, 130, 6064-6065. (m) Chen, M.-C.; Kim, C.; Chen, S.-Y.; Chaing, Y.-J.; Chung, M.-C.; Facchetti, A.; Marks, T. J. J. Mater. Chem. 2008, 18, 1029-1036. (n) Tang, M. L.; Reichardt, A. D.; Okamoto, T.; Miyaki, N.; Bao, Z. Adv. Funct. Mater. 2008, 18, 1579-1585.

(24) (a) Hong, X. M.; Katz, H. E.; Lovinger, A. J.; Wang, B.-C.; Raghavachari, K. Chem. Mater. 2001, 13, 4686-4691. (b) Ichikawa, M.; Yanagi, H.; Shimizu, Y.; Hotta, S.; Suganuma, N.; Koyama, T.; Tanigushi, Y. Adv. Mater. 2002, 14, 1272-1275. (c) Mushrush, M.; Facchetti, A.; Lefenfeld, M.; Katz, H. E.; Marks, T. J. J. Am. Chem. Soc. 2003, 125, 9414-9423. (d) Yanagi, H.; Araki, Y.; Ohara, T.; Hotta, S.; Ichikawa, M.; Taniguchi, Y. Adv. Funct. Mater. 2003, 13, 767-773. (e) Faccchetti, A.; Letizia, J.; Yoon, M.-H.; Mushrush, M.; Katz, H. E.; Marks, T. J. Chem. Mater. 2004, 16, 4715-4727. (f) Mohapatra, S.; Holmes, B. T.; Newman, C. R.; Prendergast, C. F.; Frisbie, C. D.; Ward, M. D Adv. Funct. Mater. 2004, 14, 605-609. (g) Hotta, S.; Goto, M.; Azumi, R.; Inoue, M.; Ichikawa, M.; Taniguchi, Y. Chem. Mater. 2004, 16, 237-241. (h) Ponomarenko, S. A.; Kirchmeyer, S.; Elschner, A.; Alpatova, N. M.; Halik, M.; Klauk, H.; Zschieschang, U.; Schmid, G. Chem. Mater. 2006, 18, 579-586. (i) Maunoury, J. C.; Howse, J. R.; Turner, M. L. Adv. Mater. 2007, 19, 805-809. (j) Huang, J.; Sun, J.; Katz, H. E. Adv. Mater. 2008, 20, 2567-2572. (k) Becerril, H. A.; Roberts, M. E.; Liu, Z.; Locklin, J.; Bao, Z. Adv. Mater. 2008, 20, 25882594 . accessibility. ${ }^{24}$ However, the conjugated backbone of thiophenephenylene oligomers presents a deviation from planarity due to steric interactions between thienyl and phenyl units. Theoreti$\mathrm{cal}^{25}$ and experimental results ${ }^{17,23,26-32}$ have shown that planar $\pi$-conjugated systems present better electronic couplings of $\pi$-orbitals in the solid state and hence lead to higher chargecarrier mobilities. It has been already shown that rigidification of $\pi$-conjugated systems by covalent bridging ${ }^{33-35}$ or by using fused ring building blocks ${ }^{27,36}$ leads to planar $\pi$-systems with enhanced $\pi$-electron delocalization and improved thermal stability. Thus, thiophene-based $\pi$-conjugated systems incorporating fluorene (A) or cyclopentadithiophene $(\mathbf{C})$, have demonstrated a high potential as organic semiconductors. ${ }^{30,37-41}$ Indeno$[1,2-b]$ thiophene $(\mathbf{B})$ represents an intermediate case between $\mathbf{A}$ and $\mathbf{C}$ (Chart 1). Compared to fluorene, replacement of one

(25) Coropceanu, V.; Cornil, J.; Filho, D. A.; da, Silva; Olivier, Y.; Silbey, R.; Brédas, J.-L. Chem. Rev. 2007, 107, 926-952.

(26) Laquindanum, J. G.; Katz, H. E.; Lovinger, A. J.; Dodabalapur, A. Adv. Mater. 1997, 9, 36-39.

(27) Sirringhaus, H.; Friend, R. H.; Wang, C.; Leuninger, J.; Müllen, K. J. Mater. Chem. 1999, 9, 2095-2101.

(28) (a) Li, X.-C.; Sirringhaus, H.; Garnier, F.; Holmes, A. B.; Moratti, S. C.; Feeder, N.; Clegg, W.; Teat, S. J.; Friend, R. H. J. Am. Chem. Soc. 1998, 120, 2206-2207. (b) Hunziker, C.; Zhan, X.; Losio, P. A.; Figi, H.; Know, O.-P.; Barlow, S.; Günter, P.; Marder, S. R. J. Mater. Chem. 2007, 17, 4972-4979.

(29) (a) Takimiya, K.; Kunugi, Y.; Konda, Y.; Niihara, N.; Otsubo, T. J. Am. Chem. Soc. 2004, 126, 5084-5085. (b) Yamamoto, T.; Takimiya, K. J. Am. Chem. Soc. 2007, 129, 2224-2225. (c) Ebata, H.; Izawa, T.; Miyazaki, E.; Takimiya, K.; Ikeda, M.; Kuwabara, H.; Yui, T. J. Am. Chem. Soc. 2007, 129, 1573215733. (d) Ebata, H.; Miyazaki, E.; Yamamoto, T.; Takimiya, K. Org. Lett. 2007, 9, 4499-4502.

(30) Noh, Y.-Y.; Azumi, R.; Goto, M.; Jung, B.-J.; Lim, E.; Shim, H.-K.;

Yoshida, Y.; Yase, K.; Kim, D.-Y. Chem. Mater. 2005, 17, 3861-3870.

(31) Sun, Y. M.; Ma, Y. Q.; Liu, Y. Q.; Lin, Y. Y.; Wang, Z. Y.; Wang, Y.; Di, C. A.; Xiao, K.; Chen, X. M.; Qiu, W. F.; Zhang, B.; Yu, G.; Hu, W. P.; Zhu, D. B. Adv. Funct. Mater. 2006, 16, 426-432.

(32) Cicoira, F.; Santato, C.; Melucci, M.; Favaretto, L.; Gazzano, M.; Muccini, M.; Barbarella, G. Adv. Mater. 2006, 18, 169-174.

(33) (a) Scherf, U.; Müllen, K. Makromol. Chem. Rapid Commun 1991, 12, 489-497. (b) Schlüter, A.-D.; Löffler, M.; Enkelmann, V. Nature 1994, 368, 831-834. (c) Forster, M.; Annan, K. O.; Scherf, U. Macromolecules 1999, 32, 3159-3162. (d) Scherf, U. J. Mater. Chem. 1999, 9, 1853-1864.

(34) Roncali, J. Chem. Rev. 1997, 97, 173-205.

(35) (a) Brisset, H.; Thobie-Gautier, C.; Gorgues, A.; Jubault, M.; Roncali, J. J. Chem. Soc., Chem. Commun. 1994, 1305-1306. (b) Brisset, H.; ThobieGautier, C.; Jubault, M.; Gorgues, A.; Roncali, J. J. Chem. Soc., Chem. Commun. 1994, 1765-1766. (c) Roncali, J.; Thobie-Gautier, C. Adv. Mater. 1994, 6, 846. (d) Roncali, J.; Thobie-Gautier, C.; Elandaloussi, E.; Frère, P. J. Chem. Soc., Chem Commun. 1994, 2249-2250. (e) Brisset, H.; Blanchard, P.; Illien, B.; Riou, A.; Roncali, J. Chem. Commun. 1997, 569-570. (f) Blanchard, P.; Brisset, H.; Illien, B.; Riou, A.; Roncali, J. J. Org. Chem. 1997, 62, 2401-2408. (g) Raimundo, J.-M.; Blanchard, P.; Gallego-Planas, N.; Mercier, N.; Ledoux-Rak, I.; Hierle, R.; Roncali, J. J. Org. Chem. 2002, 67, 205-218. (h) Blanchard, P.; Verlhac, P.; Michaux, L.; Frère, P.; Roncali, J. Chem. Eur. J. 2006, 12, 12441255.

(36) (a) de Bettignies, R.; Nicolas, Y.; Blanchard, P.; Levillain, E.; Nunzi, J.-M.; Roncali, J. Adv. Mater. 2003, 15, 1939-1943. (b) Nicolas, Y.; Blanchard, P.; Levillain, E.; Allain, M.; Mercier, N.; Roncali, J. Org. Lett. 2004, 6, 273276

(37) Meng, H.; Bao, Z.; Lovinger, A. J.; Wang, B.-C.; Mujsce, A. M. J. Am. Chem. Soc. 2001, 123, 9214-9215.

(38) (a) Meng, H.; Zheng, J.; Lovinger, A. J.; Wang, B.-C.; van Patten, P. G.; Bao, Z. Chem. Mater. 2003, 15, 1778-1787. (b) Locklin, J.; Li, D.; Mannsfeld, S. C. B.; Borkent, E.-J.; Meng, H.; Advincula, R.; Bao, Z. Chem. Mater. 2005, 17, 3366-3374. (c) Tang, M. L.; Roberts, M. E.; Locklin, J. J.; Ling, M. M; Meng, H.; Bao, Z. Chem. Mater. 2006, 18, 6250-6257. (d) Shin, T. J.; Yang, H.; Ling, M.-M.; Locklin, J.; Yang, L.; Lee, B.; Roberts, M. E.; Mallik, A. B.; Bao, Z. Chem. Mater. 2007, 19, 5882-5889. (e) Yuan, Q.; Mannsfeld, S. C. B.; Tang, M. L.; Roberts, M.; Toney, M. F.; DeLongchamp, D. M.; Bao, Z. Chem. Mater. 2008, 20, 2763-2772.

(39) (a) Cavallini, M.; Stoliar, P.; Moulin, J.-F.; Sorin, M.; Leclère, P.; Lazzaroni, R.; Breiby, D. W.; Andreasen, J. W. Nielsen, M. M. Sonar, P.; Grimsdale, A. C.; Müllen, K.; Biscarini, F. Nano Lett. 2005, 12, 2422-2425. (b) Thiem, H.; Strohriegl, P.; Setayesh, S.; de Leeuw, D. Synth. Met. 2006, 156, 582-589. (c) Lim, E.; Jung, B.-J.; Shim, H.-K.; Taguchi, T.; Noda, B.; Kambayashi, T.; Mori, T.; Ishikawa, K.; Takezoe, H.; Do, L.-M. Org. Electron. 2006, 7, 121-131.

(40) Yasuda, T.; Fujita, K.; Tsutsui, T.; Geng, Y.; Culligan, S. W.; Chen, S. H. Chem. Mater. 2005, 17, 264-268. 


\section{CHART 1}

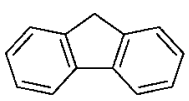

A

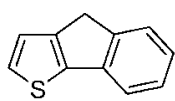

B

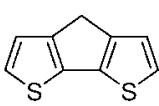

C
CHART 2
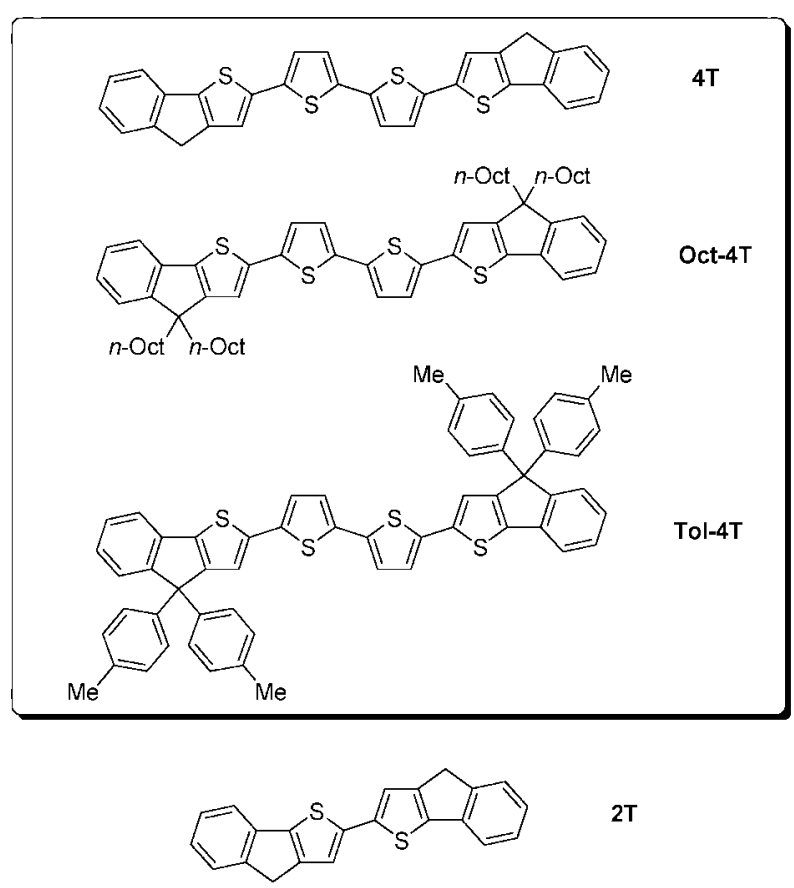

$2 T$<smiles>CCOC1(C(=O)OCc2ccccc2)c2ccccc2-c2sc(-c3cc4c(s3)-c3ccccc3C4(O)OCO)cc21</smiles>

Oct-2T
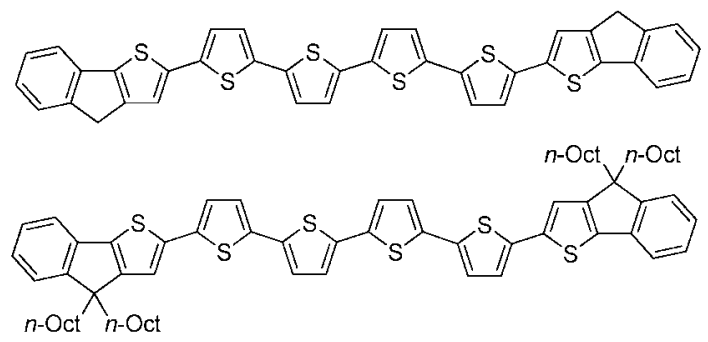

Oct-6T

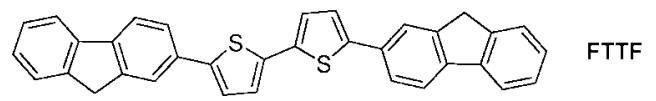

phenyl ring by a thiophene will limit steric interactions on one side and contribute to reduce the overall aromaticity of the system and thus the HOMO-LUMO gap. ${ }^{34}$

We report here the synthesis of a series of quaterthiophenes 4T, Oct-4T and Tol-4T bearing $\alpha, \omega$-terminal 4,4-unsubstituted or 4,4-disubstituted indeno[1,2- $b$ ]thiophene as well as parent oligomers obtained as side product of the synthesis (Chart 2). The electronic properties of the new compounds have been analyzed by cyclic voltammetry, UV-vis and fluorescence emission spectroscopy. Thin films of 4T, Oct-4T and Tol-4T prepared by thermal evaporation have been characterized by UV-vis and fluorescence emission spectroscopy and X-ray diffraction and preliminary results on the use of these compounds in OFETs are presented.

\section{Results and Discussion}

Synthesis. Compounds 4T, Oct-4T and Tol-4T have been synthesized by Stille $^{42}$ or Miyaura-Suzuki ${ }^{43}$ coupling of appropriate 2,2'-bithiophenes and 2-halogeno or 2-trialkylstannyl derivatives of indeno[1,2- $b]$ thiophene. The synthesis of the latter compounds is shown in Scheme 1. Indeno[1,2-b]thiophene 5 was prepared according to the McDowell procedure. ${ }^{44}$ The synthesis of $\mathbf{2}$ has been significantly improved by reacting methyl 2-bromobenzoate $\mathbf{1}$ with 2-tributylstannylthiophene in the presence of a $\operatorname{Pd}(0)$ catalyst. Saponification of ester 2 followed by acidification led to acid $\mathbf{3}$, which was subsequently converted into acid chloride. Further intramolecular Friedel-Crafts acylation afforded ketone $\mathbf{4}$. Compound $\mathbf{5}$ was obtained after a Wolf-Kishner reduction of ketone $\mathbf{4}$ and was then selectively iodinated or brominated at the 2-position by 1 equiv of $\mathrm{N}$-iodosuccinimide or $\mathrm{N}$-bromosuccinimide in DMF to give compounds 6 and 7, respectively. ${ }^{45}$ Owing to the relative acidity of the protons of the methylene bridge of $\mathbf{5}$, the 2-tributylstannyl derivative $\mathbf{8}$ was synthesized by lithium-bromine exchange on compound 7 and reaction with tributylstannyl chloride.

The synthesis of the unsubstituted quaterthiophene 4T has been carried out in different conditions summarized in Scheme 2. A Miyaura-Suzuki coupling between 2 equiv of iodo derivative 6 and pinacolato boronic ester $9^{46}$ led to 4 T in $32 \%$ yield. Alternatively, Stille couplings between bromo derivative 7 (2.5 equiv) and 5,5'-bis(tributylstannyl)-2, $2^{\prime}$-bithiophene $\mathbf{1 0}^{47}$ or stannyl derivative 8 (2.5 equiv) and 5,5'-dibromo- $2,2^{\prime}$ bithiophene $11^{48}$ gave $4 \mathrm{~T}$ in comparable yields close to $45 \%$.

As a result of its low solubility in THF or toluene, 4T precipitated in the reaction mixture and was recovered by filtration. Purification of 4T consisted of successive washings with different solvents and further Soxhlet extractions with solvents in the following order: hexane, acetone, dichloromethane, toluene, and finally chlorobenzene. The major part of $4 \mathrm{~T}$ was extracted with chlorobenzene while some amount of 4T was recovered from toluenic extracts. The lack of solubility in common deuterated organic solvents (see Experimental Section and Supporting Information) did not allow for NMR analysis at room temperature. The identity of $\mathbf{4 T}$ was confirmed by the MALDI-TOF mass spectrum of the chlorobenzene extracts, which essentially showed one main peak at $\mathrm{m} / \mathrm{z}=506$ $\left(100 \%, \mathrm{M}^{+\bullet}\right)$, associated with the related less intense isotope peaks at $m / z=507(35 \%)$ and $508(19 \%)$ (Figure S2, Supporting Information). However, another system of weak intensity was also observed with the main peak at $\mathrm{m} / \mathrm{z}=670(6 \%$ relative to the peak at $m / z=506$ ) assigned to the presence of a small amount of sexithiophene derivative 6T. This byproduct results

(41) (a) Yoon, M.-H.; DiBenedetto, S. A.; Facchetti, A.; Marks, T. J. J. Am. Chem. Soc. 2005, 127, 1348-1349. (b) Ie, Y.; Nitani, M.; Ishikawa, M.; Nakayama, K.-I.; Tada, H.; Kaneda, T.; Aso, Y. Org. Lett. 2007, 9, 2115-2118. (42) (a) Stille, J. K. Angew. Chem., Int. Ed. Engl. 1986, 25, 508-524. (b) Espinet, P.; Echevarren, A. M. Angew. Chem., Int. Ed. 2004, 43, 4704-4734.

(43) Miyaura, N.; Suzuki, A. Chem. Rev. 1995, 95, 2457-2483. 875 .

(44) MacDowell, D. W. H.; Jeffries, A. T. J. Org. Chem. 1970, 35, 871-

(45) (a) Bäuerle, P.; Würthner, F.; Götz, G.; Effenberger, F. Synthesis 1993, 1099-1103. (b) Bäuerle, P.; Götz, G.; Synowczyk, A.; Heinze, J. Liebigs Ann. 1996, 279-284.

(46) Usta, H.; Lu, G.; Facchetti, A.; Marks, T. J. J. Am. Chem. Soc. 2006, 128, 9034-9035.

(47) (a) Wie, Y.; Yang, Y.; Yeh, J.-M. Chem. Mater. 1996, 8, 2659-2666. (b) Jousselme, B.; Blanchard, P.; Levillain, E.; Delaunay, J.; Allain, M.; Richomme, P.; Rondeau, D.; Gallego-Planas, N.; Roncali, J. J. Am. Chem. Soc. 2003, 125, 1363-1370.

(48) Tamao, K.; Kodama, S.; Nakajima, I.; Kumada, M.; Minato, A.; Suzuki, K. Tetrahedron 1982, 38, 3347-3354. 


\section{SCHEME 1}<smiles>CC(=O)c1ccccc1Br</smiles>

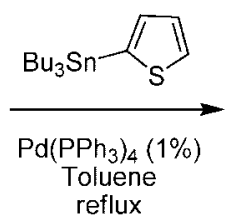

reflux<smiles>CC(=O)c1ccccc1-c1cccs1</smiles>

$2(98 \%)$

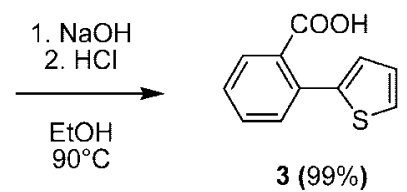

$3(99 \%)$

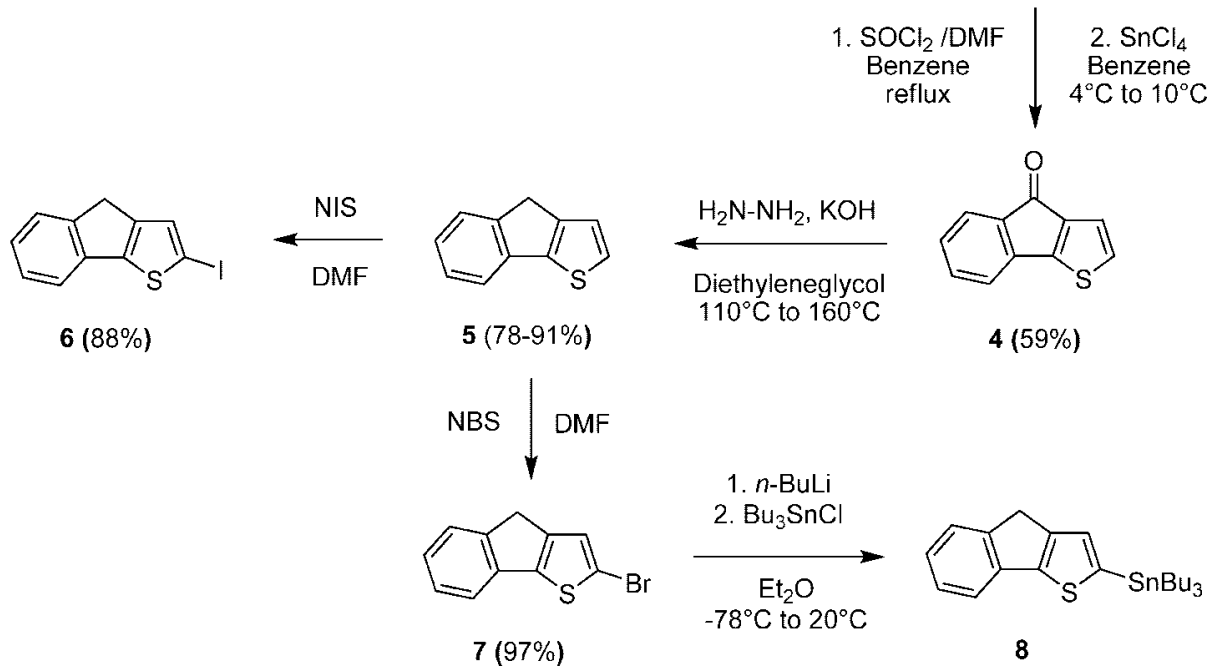

SCHEME 2<smiles>CC1(C)OB(c2ccc(-c3ccc(B4OC(C)(C)C(C)([I+])O4)s3)s2)OC1(C)C</smiles>

$\mathrm{Pd}\left(\mathrm{PPh}_{3}\right)_{4}$

336 Aliquat, $\mathrm{Na}_{2} \mathrm{CO}_{3}$

$\mathrm{THF} / \mathrm{H}_{2} \mathrm{O}$

$32 \%$

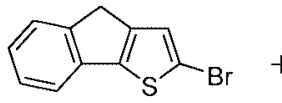<smiles>CCCCCCCCCCCCCCCCCCCC</smiles>

8<smiles>Brc1ccc(-c2ccc(Br)s2)s1</smiles>

11<smiles>CCCCc1ccc(-c2ccc(CSCCC)s2)s1</smiles>

10

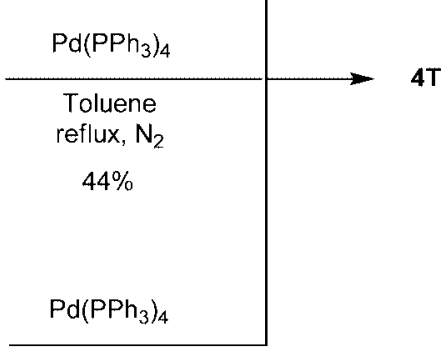

Toluene reflux, $\mathrm{N}_{2}$

$48 \%$

from an initial homocoupling of bithiophene derivatives 9-11 during Stille or Miyaura-Suzuki reaction. Such Stille homocoupling has already been observed during the synthesis of other oligothiophenes. ${ }^{49}$ Interestingly the MALDI-TOF data of the toluenic extracts show the presence of only 4T (Figure S2, Supporting Information). Similarly, the indenothiophene compounds $6-8$ used in the synthesis of $\mathbf{4 T}$ were also subjected to homocouplings leading to the formation of bithiophene $2 \mathrm{~T}$.

With the aim of developing an alternative route to $4 \mathrm{~T}$ free of $\mathbf{6 T}$, the soluble precursor $\mathbf{1 3}$ was synthesized by reacting 2.5 equiv of stannyl compound 8 with 1 equiv of $3,3^{\prime}-$ bis(trimethylsilyl)-5,5'-dibromo-2,2'-bithiophene $\mathbf{1 2}^{\mathbf{2 3 h}}$ (Scheme 3 ). As recently reported, ${ }^{23 \mathrm{~h}}$ the bulky trimethylsilyl groups of

(49) Van Hal, P. A.; Beckers, E. H. A.; Meskers, S. C. J.; Janssen, R. A. J.; Jousselme, B.; Blanchard, P.; Roncali, J. Chem. Eur. J. 2002, 8, 5415-5429. these intermediate compounds strongly enhance their solubility. Purification of $\mathbf{1 3}$ was performed by successive silica gel column chromatography and preparative thick layer chromatography to get rid of sexithiophene traces. The subsequent cleavage of the trimethylsilyl groups of $\mathbf{1 3}$ in the presence of fluoride anions led to pure 4T, which was recovered by simple filtration. As expected, the MALDI-TOF spectrum of $4 \mathbf{T}$ confirmed the absence of 6T. Moreover, the mass spectrum recorded between $\mathrm{m} / \mathrm{z}=0$ and 1500 shows only the presence of the molecular ion peak at $\mathrm{m} / \mathrm{z}=506$ with the corresponding isotope peaks, thus suggesting a good purity for this sample (Figure S3, Supporting Information). The ${ }^{1} \mathrm{H}$ NMR spectrum of 4T recorded in $\mathrm{CDCl}_{3}$ at $55{ }^{\circ} \mathrm{C}$ or in DMSO- $d_{6}$ at $90{ }^{\circ} \mathrm{C}$ (Figures $\mathrm{S} 18$ and S19, Supporting Information), respectively, shows a very weak singlet at 3.72 or $3.80 \mathrm{ppm}$ corresponding to the protons of the two methylene bridges, suggesting that compound 4T is pure. 


\section{SCHEME 3}

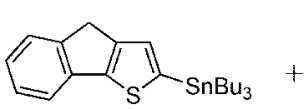

8<smiles>C[SiH2]c1cc(Br)sc1-c1sc(Br)cc1[SiH3]</smiles>
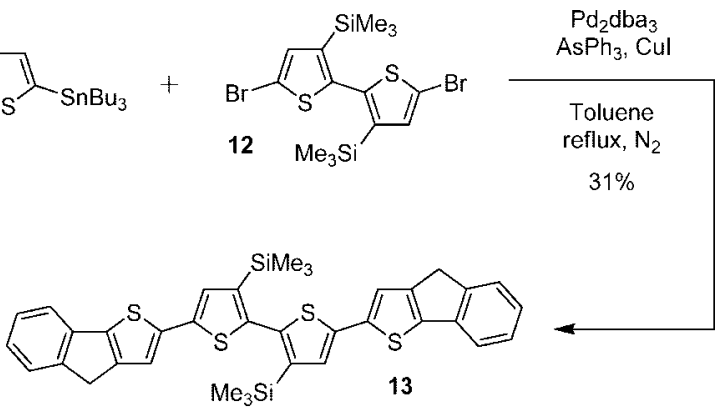

\begin{tabular}{l|l}
$n-\mathrm{Bu}_{4} \mathrm{NF}$ \\
Pyridine & $51 \%$
\end{tabular}

4T

\section{SCHEME 4}
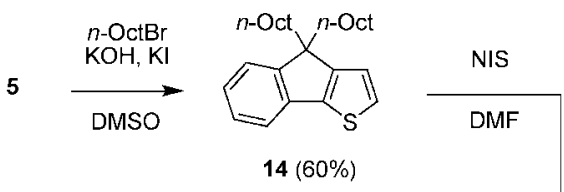

16

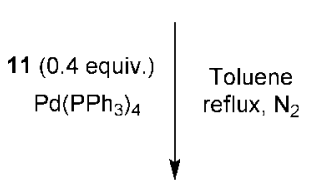

Oct-2T (Traces)

Oct-4T $(66 \%)$

Oct-6T $(16 \%)$

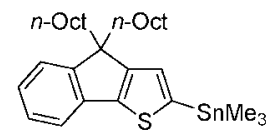

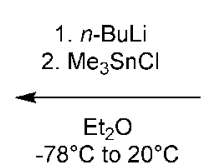

$-78^{\circ} \mathrm{C}$ to $20^{\circ} \mathrm{C}$

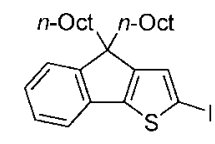

$15(92 \%)$

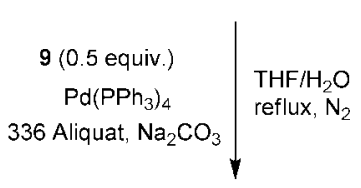

Oct-2T (27\%)

Oct-4T $(24 \%)$ Oct-6T (Traces)
However, assignment of the aromatic protons is still prevented by the weakness of the NMR signals.

Analogs more soluble than 4T have been obtained by substitution at the methylene bridges by $n$-octyl chains and p-tolyl groups leading to compounds Oct-4T and Tol-4T, respectively. Compound Oct-4T was prepared either by Miyaura-Suzuki coupling of iodinated compound 15 with pinacolato boronic ester 9 or by Stille coupling of stannyl derivative 16 with 5,5'-dibromo 2,2'-bithiophene 11 (Scheme 4). Compound 16 was obtained from 15 after successive lithium-iodine exchange and reaction with trimethylstannyl chloride. Compound $\mathbf{1 5}$ was prepared from $\mathbf{5}$ by double alkylation with $n$-octylbromide in basic conditions leading to the 4,4-substituted indenothiophene $\mathbf{1 4}$, which was then iodinated using $N$-iodosuccinimide.

In the case of the Suzuki coupling, Oct-4T was obtained in modest yield $(24 \%)$, whereas the main product was 2,2'bithiophene Oct-2T (27\%). Only traces of sexithiophene Oct6T were observed. The use of Stille conditions improved the yield of Oct-4T to 66\%, while 16\% yield of sexithiophene Oct6T and traces of bithiophene Oct-2T were obtained.

Based on the preceding results, compound Tol-4T was prepared in $53 \%$ yield by Stille reaction between 5,5'-dibromo2,2'-bithiophene $\mathbf{1 1}$ and the stannyl derivative $\mathbf{1 9}$ in the presence

\section{SCHEME 5}
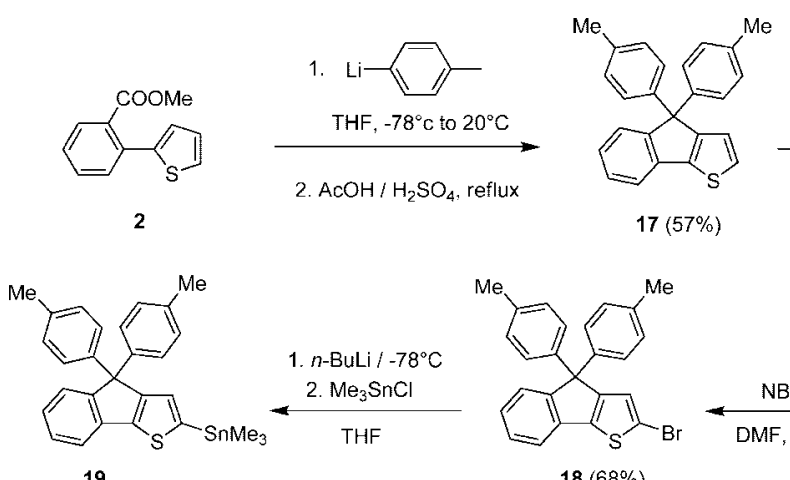

19

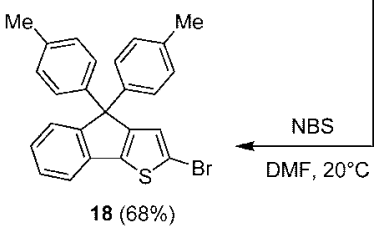

$18(68 \%)$

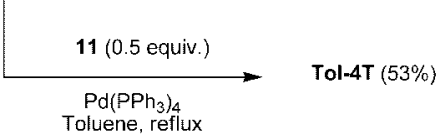

TABLE 1. UV-vis Absorption, Fluorescence Emission, and Cyclic Voltammetric Data for Oligothiophenes

\begin{tabular}{llcccc}
\hline compd & \multicolumn{1}{c}{$\lambda_{\max }, \mathrm{nm}^{a}$} & \multicolumn{1}{c}{$\lambda_{\mathrm{em}}, \mathrm{nm}^{b}$} & $\Phi, \%$ & $E_{\mathrm{pa}}{ }^{1}, \mathrm{~V}^{c}$ & $E_{\mathrm{pa}}{ }^{2}, \mathrm{~V}^{c}$ \\
\hline 2T & $380, \mathbf{3 9 7}, 417$ & $\mathbf{4 4 0 , 4 6 6 , 4 9 5}$ & 6 & 0.85 & 1.33 (irr) \\
$\mathbf{4 T}$ & 442 & $512,545,595$ & 26 & & \\
Oct-2T & $391, \mathbf{4 0 8}, 427$ & $\mathbf{4 5 1}, 477,510$ & 4 & 0.84 & 1.30 (irr) \\
Oct-4T & 450 & $516,550,600$ & 31 & 0.75 & 0.93 \\
Oct-6T & 470 & $544,582,640$ & 18 & 0.68 & 0.82 \\
Tol-4T & 452 & $517,550,600$ & 27 & 0.79 & 1.00
\end{tabular}

${ }^{a}$ Absorption maxima in $\mathrm{CH}_{2} \mathrm{Cl}_{2}$. ${ }^{b}$ Emission maxima in $\mathrm{CH}_{2} \mathrm{Cl}_{2}$ with perylene $(\Phi=92 \%$ in $\mathrm{EtOH})$ as standard. Bold numbers represent the more intense absorption or emission bands. ${ }^{c} 1 \mathrm{mM}$ substrate in $0.10 \mathrm{M}$ $n-\mathrm{Bu}_{4} \mathrm{NPF}_{6} / \mathrm{CH}_{2} \mathrm{Cl}_{2}$, scan rate $100 \mathrm{mV} \mathrm{s}^{-1}$, Pt working electrode, ref SCE.

of $\mathrm{Pd}\left(\mathrm{PPh}_{3}\right)_{4}$ (Scheme 5). Compound 19 was obtained from $\mathbf{1 8}$ by lithium-bromine exchange and reaction with trimethylstannyl chloride. Bromination of compound 17 with $N$-bromosuccinimide in DMF gave the bromo derivative $18 .{ }^{50}$ Compound 17 was prepared by reacting $p$-tolyllithium, generated by reaction of $n$-BuLi on $p$-bromotoluene, with ester 2 to give an intermediate alcohol which was then cyclized into $\mathbf{1 7}$ in acidic conditions.

Electrochemical and Optical Properties. The electrochemical properties of new compounds have been analyzed by cyclic voltammetry $(\mathrm{CV})$ in dichloromethane in the presence of tetrabutylammonium hexafluorophosphate as supporting electrolyte. Table 1 lists CV, UV-vis absorption, and fluorescence emission data for oligothiophenes derivatives. The CV of 4T could not be recorded because of insufficient solubility. The $\mathrm{CV}$ of $2 \mathrm{~T}$ presents a one-electron reversible oxidation peak at $E_{\mathrm{pa}}{ }^{1}=0.85 \mathrm{~V}$ corresponding to the generation of a stable radical cation followed by an irreversible oxidation peak at more positive potential (Figure S4, Supporting Information).

Figure S5 in Supporting Information shows the CV traces of Oct-2T, Oct-4T, and Oct-6T. Compound Oct-2T exhibits a one-electron reversible oxidation peak at $E_{\mathrm{pa}}{ }^{1}=0.84 \mathrm{~V}$ and an ill-defined irreversible oxidation wave around $1.30 \mathrm{~V}$ (not shown). The CV of Oct-4T shows two reversible one-electron oxidation peaks at $E_{\mathrm{pa}}{ }^{1}=0.75 \mathrm{~V}$ and $E_{\mathrm{pa}}{ }^{2}=0.93 \mathrm{~V}$, associated with the formation of stable radical cation and dication. As expected, insertion of additional thiophene rings from Oct-2T to Oct-4T and Oct-6T produces a negative shift of $E_{\mathrm{pa}}{ }^{1}$ and

(50) Wong, K.-T.; Hwu, T.-Y.; Balaiah, A.; Chao, T.-C.; Fang, F.-C.; Lee, C.-T.; Peng, Y.-C. Org. Lett. 2006, 8, 1415-1418. 

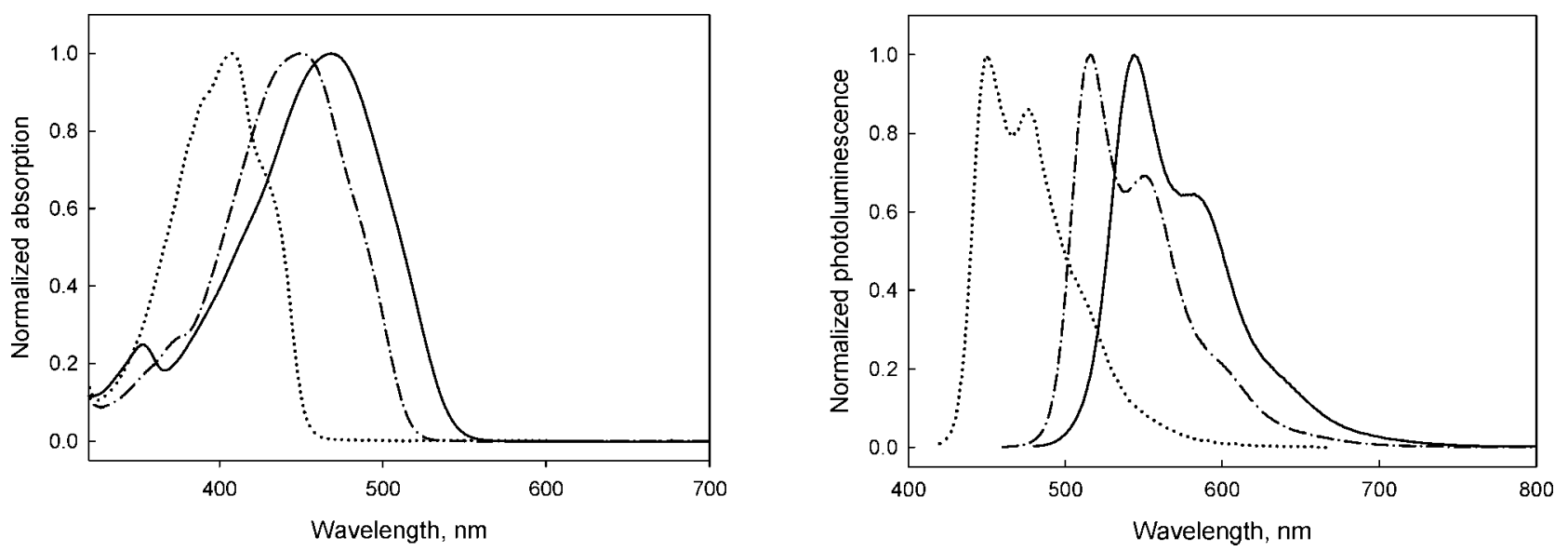

FIGURE 1. Normalized absorption and photoluminescence spectra of Oct-2T (dotted line), Oct-4T (dashed-dotted line), and Oct-6T (solid line) in $\mathrm{CH}_{2} \mathrm{Cl}_{2}$.

$E_{\mathrm{pa}}^{2}$, while the difference $\Delta E_{\mathrm{pa}}=E_{\mathrm{pa}}^{2}-E_{\mathrm{pa}}^{1}$ decreases from Oct-4T $(180 \mathrm{mV})$ to Oct-6T $(140 \mathrm{mV})$ due to the smaller Coulombic repulsion in the dicationic state as chain length increases. Replacement of $n$-octyl chains of Oct-4T by $p$-tolyl groups in Tol-4T leads to a positive shift of $40 \mathrm{mV}$ and $70 \mathrm{mV}$ of the $E_{\mathrm{pa}}{ }^{1}$ and $E_{\mathrm{pa}}{ }^{2}$ values, respectively (Figure S6, Supporting Information).

The absorption and emission spectra of $\mathbf{4 T}$ are shown in Figure S7, Supporting Information. A broad absorption band attributed to a $\pi-\pi^{*}$ transition is observed at $\lambda_{\max }=442 \mathrm{~nm}$, while the emission spectrum exhibits a more resolved vibronic structure with the most populated $0-0$ transition at $512 \mathrm{~nm}$, a less intense peak at $545 \mathrm{~nm}$, and a shoulder at $595 \mathrm{~nm}$. Similar spectra are observed for Oct-4T and Tol-4T, although substitution of the indeno[1,2- $b]$ thiophene heterocycle leads to a slight red shift of absorption and emission maxima (Table 1).

The UV-vis spectrum of compound $\mathbf{1 3}$ shows an absorption maximum at $379 \mathrm{~nm}$, and the $\sim 63 \mathrm{~nm}$ blue shift compared to 4T agrees well with the restricted conjugation imposed by the twisted structure of the molecule (Figure S7, Supporting Information).

Figure 1 shows the absorption and emission spectra of oligothiophenes of the octyl series. As expected, increasing the length of the $\pi$-conjugated system from two to six thiophene rings leads to a progressive red shift of the maximum of absorption associated with the reduction of the HOMO-LUMO gap $(\Delta E)$. The latter can be estimated from the absorption edges in the UV-vis spectra of Oct-2T $(\Delta E=2.7 \mathrm{eV})$, Oct-4T $(\Delta E=2.4 \mathrm{eV})$, and Oct-6T $(\Delta E=2.3 \mathrm{eV})$.

Theoretical Calculations. Theoretical calculations on $4 \mathrm{~T}$ and a reference compound fluorene-thiophene-thiophene-fluorene (FTTF) (Chart 2), which has recently demonstrated great potential as active material in OFETs, ${ }^{37,38}$ have been performed at the ab initio density functional level with the Gaussian 03 program. Becke's three-parameter gradient corrected functional (B3LYP) with a polarized 6-31G(d,p) basis was used for all full geometry optimizations. In both cases, the oligothiophene chain adopts an anti conformation. As expected, 4T presents a more planar structure than FTTF. While the dihedral angles between the thiophene rings of the central bithiophene core are comparable for $4 \mathbf{T}\left(13^{\circ}\right)$ and for FTTF $\left(10^{\circ}\right)$, the dihedral angles between the terminal indeno[1,2-b]thiophene unit $\left(14^{\circ}\right)$ or the terminal fluorene unit $\left(25^{\circ}\right)$ and the vicinal thiophene ring differ significantly (Figure 2). This difference results in a decrease of the calculated $\Delta E$ from $3.18 \mathrm{eV}$ for FTTF to $2.74 \mathrm{eV}$ for $\mathbf{4 T}$,
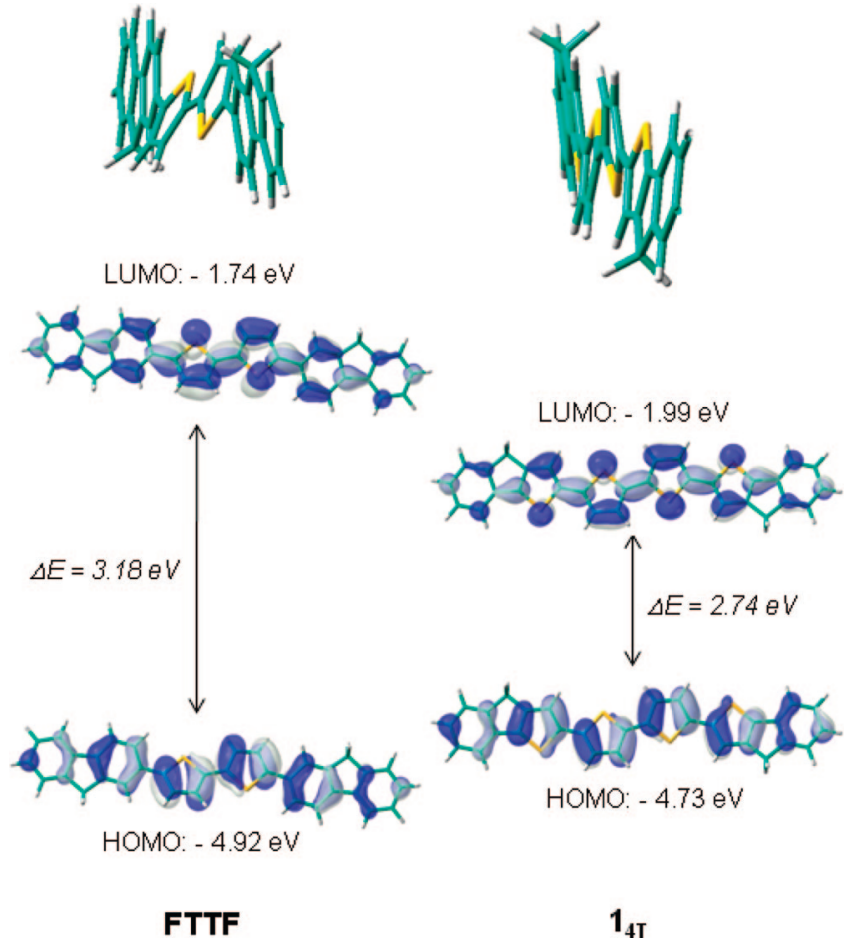

HOMO: -4.73 eV

FIGURE 2. Optimized structures and energy levels of HOMO and LUMO of FTTF and 4 T.

which stems from the concomitant $+0.19 \mathrm{eV}$ increase of the HOMO level and $-0.25 \mathrm{eV}$ decrease of the LUMO level. Interestingly, the LUMO level is more affected than the HOMO level. The HOMO and LUMO of both molecules show typical aromatic and quinoid characters, respectively, with an extension of $\pi$-conjugation over the whole conjugated backbone.

Film Characterizations. Films of 4T, Oct-4T, and Tol-4T have been grown on glass by sublimation of $4 \mathrm{~T}$, Oct-4T, or Tol-4T under high vacuum. The absence of degradation of the molecules during vacuum sublimation was confirmed by checking the UV-vis absorption spectrum of the redissolved films.

Although 4T, Oct-4T, and Tol-4T show similar UV-vis spectra in solution, those of the corresponding thin films exhibit three drastically different behaviors. Thus, comparison of the solution and the solid-state spectra of $4 \mathrm{~T}$ reveals a $57 \mathrm{~nm}$ blue shift of $\lambda_{\max }$ and the appearance of a weak electronic transition at $510 \mathrm{~nm}$ for the film (Figure 3, top). As already observed for 

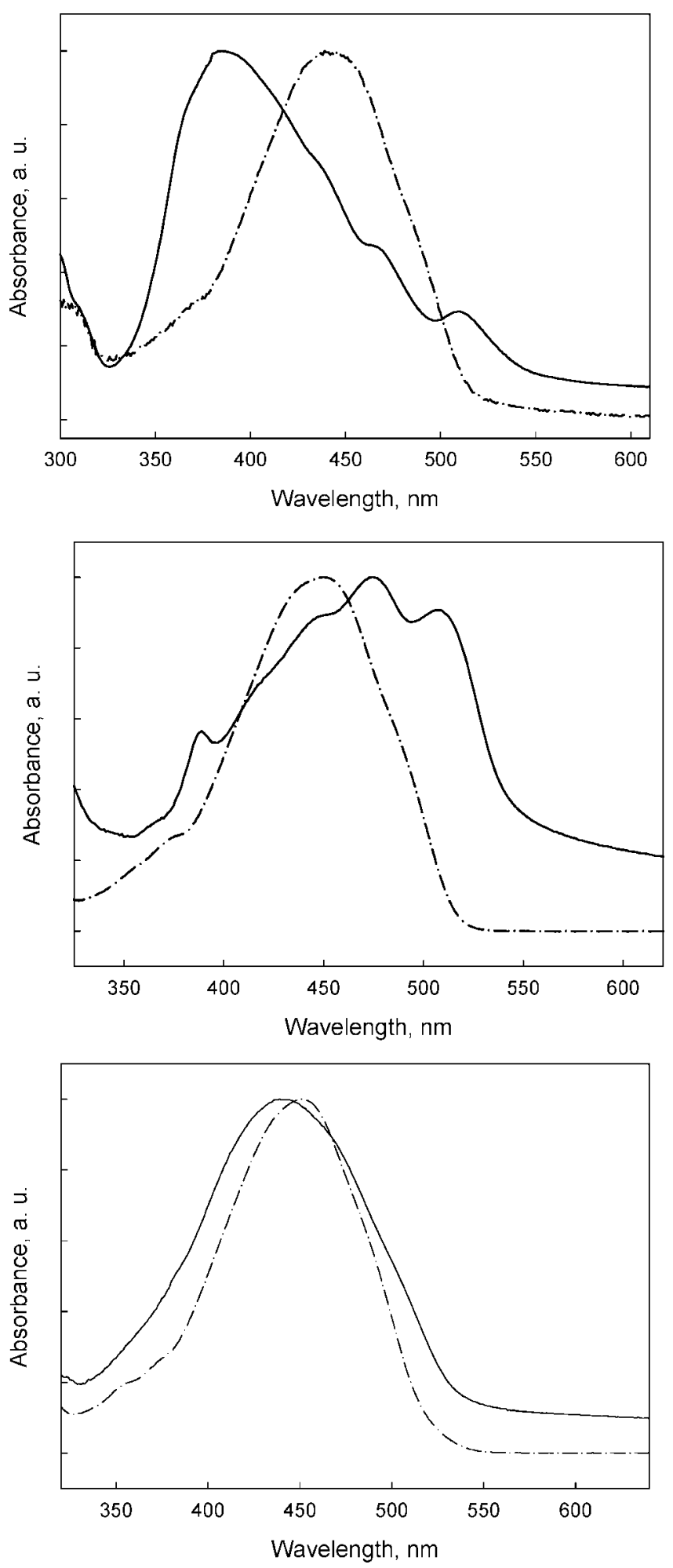

FIGURE 3. Absorption spectra of 4 T (top), Oct-4T (middle), and Tol$4 \mathrm{~T}$ (bottom) as films on glass (solid line) or in $\mathrm{CH}_{2} \mathrm{Cl}_{2}$ (dashed-dotted line).

other oligothiophenes, $1,19,20,21 \mathrm{a}, \mathrm{c}, 22,51$ this behavior results from a Davydov splitting of the singlet excited state that is generally associated with strongly interacting $\pi$-conjugated systems in the solid state.

(51) Roncali, J.; Frère, P.; Blanchard, P.; de Bettignies, R.; Turbiez, M.; Roquet, S.; Leriche, P.; Nicolas, Y. Thin Solid Films 2006, 511-512, 567-575.
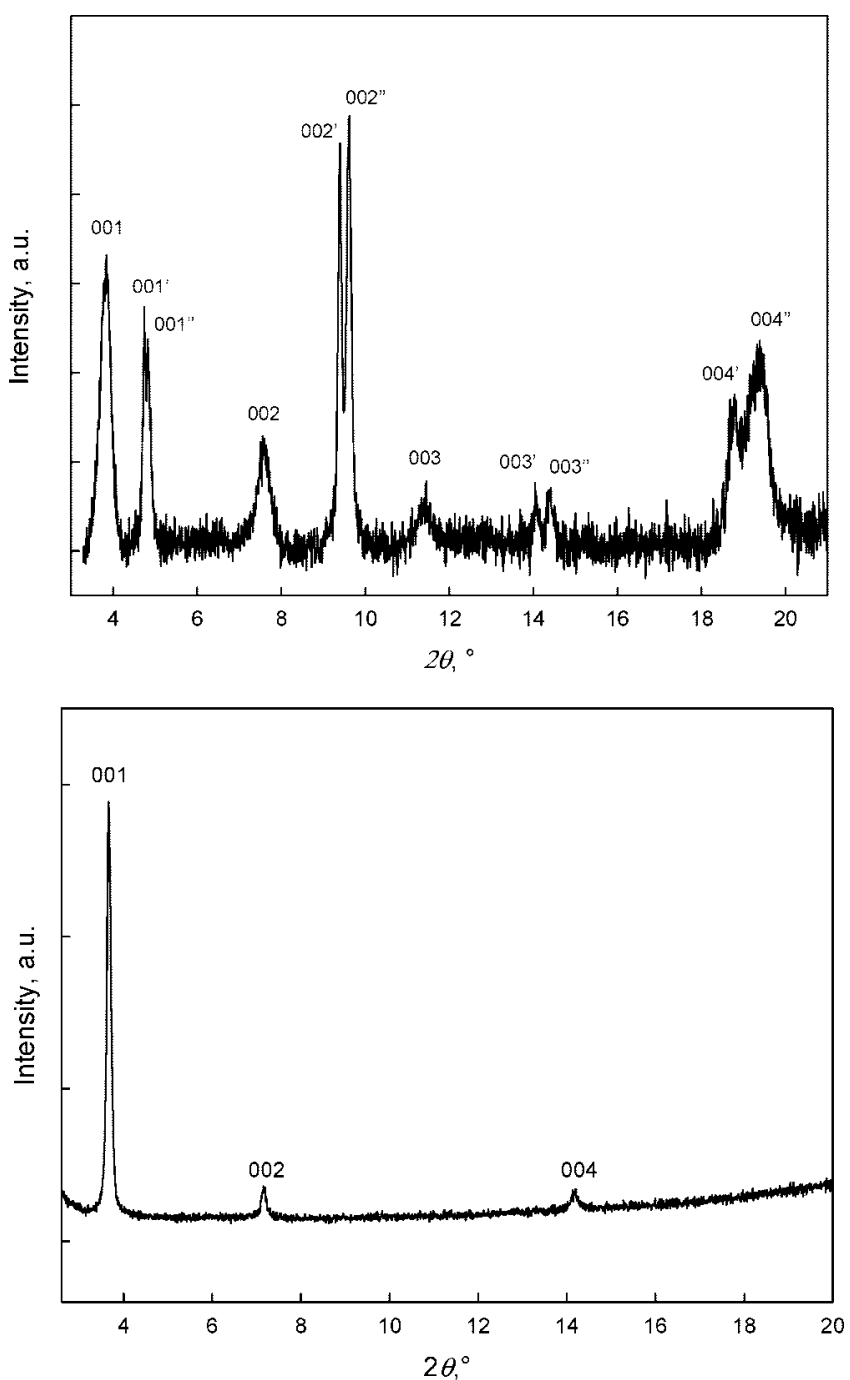

FIGURE 4. X-ray diffraction diagrams of films of $50 \mathrm{~nm}$ thickness of 4T (top) and Oct-4T (bottom) on glass.

The solid-state optical spectrum of Oct-4T shows a wellresolved vibronic structure. However, in contrast to $4 \mathrm{~T}$, a red shift in absorbance typical of the formation of $J$ aggregates ${ }^{52}$ and a broadening of the absorption band of Oct-4T are observed in the solid state (Figure 3, middle), suggesting weaker intermolecular $\pi$-interactions and a different molecular arrangement. On the other hand, the similarity of the UV-vis spectrum of Tol-4T obtained in solution or as film indicates limited $\pi$-intermolecular interactions in the solid state (Figure 3, bottom).

In addition, the quenching of the fluorescence for the film of 4T and the persistence of fluorescence properties for films of Oct-4T and Tol-4T (Figure S9, Supporting Information) agree well with the expected weaker intermolecular $\pi$-interactions in the two latter cases.

Films of $50 \mathrm{~nm}$ thickness of 4T, Oct-4T, and Tol-4T have been analyzed by X-ray diffraction in reflection mode. The XRD diagram of a film of Tol-4T shows the absence of diffraction peaks indicating an amorphous character (Figure S10, Supporting Information). By contrast, films of 4 T and Oct-4T show a

(52) (a) Mishra, A.; Behera, R. K.; Behera, P. K.; Mishra, B. K.; Behera, G. B. Chem. Rev. 2000, 100, 1973-2011. (b) Dautel, O. J.; Wantz, G.; Almairac, R.; Flot, D.; Hirsch, L.; Lère-Porte, J.-P.; Parneix, J.-P.; Serein-Spirau, F.; Vignau, L.; Moreau, J. J. E. J. Am. Chem. Soc. 2006, 128, 4892-4901. 

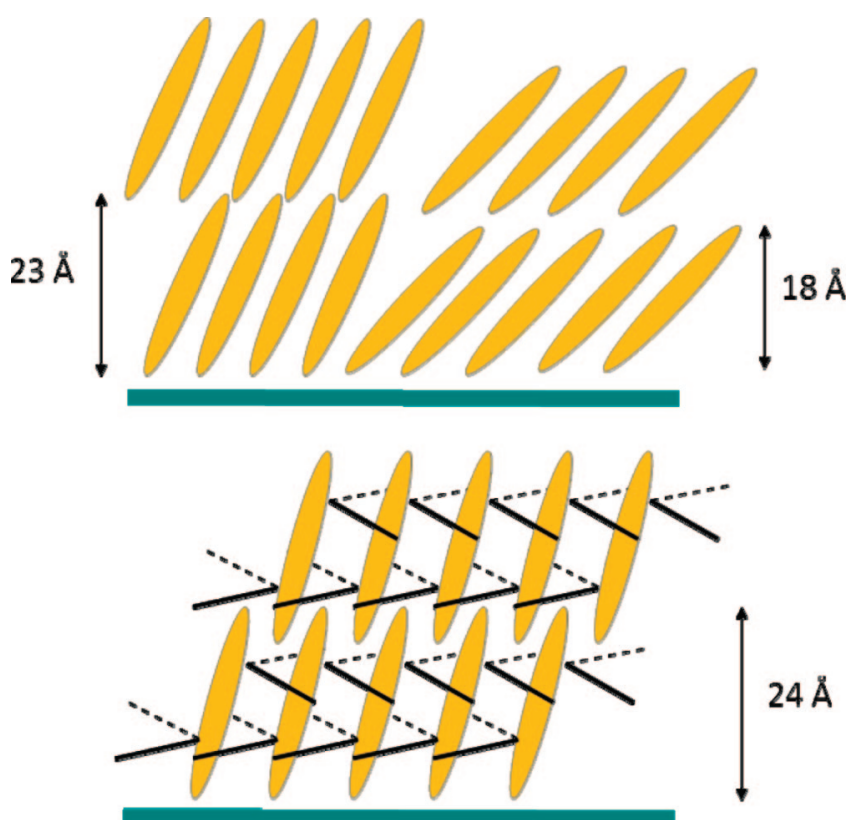

FIGURE 5. Possible structures for films of $\mathbf{4 T}$ (top) and Oct-4T (bottom).

crystalline character and are highly ordered as evidenced by sharp diffraction peaks (Figure 4). The XRD diagram for 4T exhibits various peaks among them three different first order diffraction peaks $(001),\left(001^{\prime}\right)$, and $\left(001^{\prime \prime}\right)$ at $2 \theta$ values of $3.83^{\circ}$, $4.76^{\circ}$, and $4.84^{\circ}$, which correspond to the respective $d$-spacings of $23.0,18.5$, and $18.2 \AA\left(\lambda_{\mathrm{Cu}-\alpha}=1.5406 \AA\right)$. Assuming a fully extended linear structure for $\mathbf{4 T}$ with all vicinal thiophene rings in an anti conformation, the MM2 minimized length of 4T was estimated to $25 \AA$. Hence, these results suggest that three crystalline domains coexist in the film where the long axis of molecules $\mathbf{4 T}$ is tilted relative to the normal of the surface with the angle values of $23^{\circ}, 42^{\circ}$, and $43^{\circ}$. Figure 5 (top) represents a schematic description of the film structure of $4 \mathbf{T}$.

The XRD diagram of a film of Oct-4T shows one intense diffraction peak $(001)$ at $2 \theta=3.65^{\circ}$ and two weak peaks corresponding to higher orders of diffraction. These peaks lead to a molecular layer of $24.2 \AA$ of thickness. Using the molecular length calculated for 4T, molecules Oct-4T adopt a quasivertical orientation relative to the surface with an estimated tilt angle of $15^{\circ}$ with, however, weaker intermolecular $\pi$-interactions due to the presence of the $n$-octyl chains, (Figure 5 , bottom) in agreement with UV-vis results.

OFET Fabrication and Measurements. TGA and DSC measurements (see Supporting Information) showed that quaterthiophenes 4T, Oct-4T, and Tol-4T presented high thermal stability compatible with a sublimation process. On this basis, top-contact OFETs were made by deposition of a film of 50 nm thickness of 4T, Oct-4T, and Tol-4T onto a substrate kept at $20{ }^{\circ} \mathrm{C}$ of a heavily doped silicon with a $200 \mathrm{~nm}$ thick $\mathrm{SiO}_{2}$ layer as dielectric, and the devices were completed by gold top contact source and drain electrodes.

Devices realized from the octyl (Oct-4T)- and tolyl (Tol4T)-substituted quaterthiophenes did not show any field-effect behavior, as could be expected from the already discussed weak intermolecular interactions. Figure 6 presents the drain current versus drain-source voltage $\left(I_{\mathrm{DS}} / V_{\mathrm{DS}}\right)$ curves at different gate voltages $\left(V_{\mathrm{G}}\right)$ of an OFET based on 4T. The drain current increases with increasing negative gate voltage, as expected for

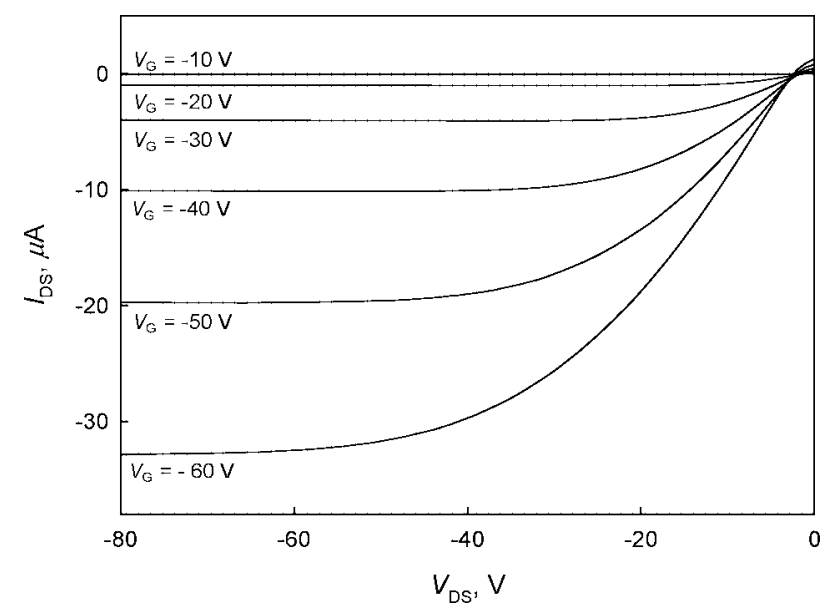

FIGURE 6. $I_{\mathrm{DS}}$ versus $V_{\mathrm{DS}}$ characteristics at different $V_{\mathrm{G}}$ values for an OFET based on an evaporated layer of 4T, channel length $L=50$ $\mu \mathrm{m}$ and channel width $W=5 \mathrm{~mm}$.

a $p$-type semiconductor. A field-effect mobility $\mu$ of $2.2 \times 10^{-2}$ $\mathrm{cm}^{2} \mathrm{~V}^{-1} \mathrm{~s}^{-1}$ corresponding to an average of eight devices was obtained at a drain voltage of $-80 \mathrm{~V}$. The transfer characteristics and the $\log \left(I_{\mathrm{DS}}\right)$ versus $V_{\mathrm{G}}$ curve (Figure S11, Supporting Information) give an average threshold voltage $V_{\mathrm{T}}$ of $-16.9 \mathrm{~V}$ and an average on/off ratio of $2.2 \times 10^{4}$, respectively. Using similar conditions, Bao et al. have reported a field-effect mobility of $2-3 \times 10^{-2} \mathrm{~cm}^{2} \mathrm{~V}^{-1} \mathrm{~s}^{-1}$ with on/off ratios of $10^{5}-10^{6}$ for OFETs based on FTTF. ${ }^{37}$

\section{Conclusion}

Quaterthiophene derivatives 4T, Oct-4T, and Tol-4T based on a central 2,2'-bithiophene core with two terminal 4,4unsubstituted or 4,4-disubstituted indeno[1,2- $b]$ thiophene heterocycles have been synthesized using Stille or Miyaura-Suzuki couplings. While complete characterization of the unsubstituted derivative 4T of the series was prevented because of its lack of solubility in common organic solvents, the introduction of $n$-octyl chains or $p$-tolyl groups at the 4-positions of the indeno $[1,2-b]$ thiophene moiety led to more soluble compounds Oct-4T and Tol-4T. Moreover, a detailed study of the synthesis of quaterthiophene Oct-4T has evidenced the formation of byproduct such as bithiophene Oct-2T and sexithiophene Oct6T resulting from homocoupling reactions. These side reactions that make the purification of insoluble derivative 4T difficult led us to adopt an alternative synthetic route involving a soluble precursor for the synthesis of $\mathbf{4 T}$.

Optical and X-ray diffraction results show that sublimed films of 4T and Oct-4T are highly crystalline with molecules adopting a quasivertical orientation on the substrate, whereas films of Tol-4T are amorphous. Strong $\pi-\pi$ intermolecular interactions in the case of $\mathbf{4 T}$ allow for the realization of OFET with interesting hole-mobilities and on/off ratios, while such interactions are hindered by the presence of the $n$-octyl chains of Oct-4T.

Work focused on the development of new conjugated systems based on the indenothiophene building block and combining solubility and strong intermolecular interactions is now underway and will be reported in future publications.

\section{Experimental Section}

Devices Preparation and Characterization. Organic FETs were prepared by evaporation of 4T, Oct-4T, and Tol-4T under a vacuum 
of $6 \times 10^{-7}$ mbar and subsequent deposition of a $50 \mathrm{~nm}$ thick organic layer at a rate of $0.2 \mathrm{~nm} \mathrm{~s}^{-1}$ onto $\mathrm{Si} \mathrm{n}++$ wafer with a 200 nm thick $\mathrm{SiO}_{2}$ layer (ACM) with a substrate temperature of $20^{\circ} \mathrm{C}$. As source and drain top contacts, $50 \mathrm{~nm}$ of $\mathrm{Au}$ were evaporated through a homemade shadow mask, defining a channel of 5000 $\mu \mathrm{m}$ width and $50 \mu \mathrm{m}$ length. The characterization was carried out in a glovebox using an Agilent $4155 \mathrm{C}$ semiconductor parameter analyzer. The contacts were obtained by W tips (Signatone). For evaluation of the mobility $(\mu)$ in the saturation regime, the following equation was used:

$$
I_{\mathrm{DS}}(\mathrm{sat})=(W / 2 L) \mu C_{\mathrm{i}}\left(V_{\mathrm{G}}-V_{\mathrm{T}}\right)^{2}
$$

where $I_{\mathrm{DS}}$ is the drain current, $V_{\mathrm{G}}$ is the gate voltage, $V_{\mathrm{T}}$ is the extrapolated threshold voltage, $\mu$ is the field-effect mobility, $L$ and $W$ are the channel length and width, respectively, and $C_{\mathrm{i}}$ is the insulator capacitance per unit area.

2-Iodo-4H-indeno[1,2-b]thiophene (6). A solution of $\mathrm{N}$-iodosuccinimide $(2.7 \mathrm{~g}, 12.7 \mathrm{mmol})$ in DMF $(60 \mathrm{~mL})$ was added dropwise to a solution of 5 (2 g, $11.6 \mathrm{mmol})$ in DMF $(60 \mathrm{~mL})$ cooled to $0{ }^{\circ} \mathrm{C}$ and protected from the daylight. The reaction mixture was stirred for $1 \mathrm{~h}$ at $0{ }^{\circ} \mathrm{C}$ and then allowed to reach room temperature. Water $(450 \mathrm{~mL})$ was added, and the resulting white precipitate was filtered and washed with water $(2 \times 50 \mathrm{~mL})$ giving, after drying, 6 (3.06 g, 88\% yield) as white powder. Mp 91-92 ${ }^{\circ} \mathrm{C} .{ }^{1} \mathrm{H}$ NMR $\left(500 \mathrm{MHz}, \mathrm{CDCl}_{3}\right): \delta 3.69(\mathrm{~s}, 2 \mathrm{H}), 7.21\left(\mathrm{t}, 1 \mathrm{H},{ }^{3} \mathrm{~J}=\right.$ $7.5 \mathrm{~Hz}), 7.29(\mathrm{~s}, 1 \mathrm{H}), 7.32\left(\mathrm{t}, 1 \mathrm{H},{ }^{3} J=7.5 \mathrm{~Hz}\right), 7.44\left(\mathrm{~d}, 1 \mathrm{H},{ }^{3} J=\right.$ $7.5 \mathrm{~Hz}), 7.48\left(\mathrm{~d}, 1 \mathrm{H},{ }^{3} J=7.5 \mathrm{~Hz}\right)$. MS $(70 \mathrm{eV}, \mathrm{EI}) \mathrm{m} / \mathrm{z}$ $(\mathrm{I} \%)=298\left(\mathrm{M}^{+\bullet}, 100\right), 171(55)$.

2-Bromo-4H-indeno[1,2-b]thiophene (7). A solution of $\mathrm{N}$ bromosuccinimide $(1.08 \mathrm{~g}, 6.1 \mathrm{mmol})$ in DMF $(30 \mathrm{~mL})$ was added dropwise to a solution of $\mathbf{5}(1 \mathrm{~g}, 5.8 \mathrm{mmol})$ in DMF $(30 \mathrm{~mL})$ cooled to $0{ }^{\circ} \mathrm{C}$ and protected from the daylight. The resulting solution was stirred for $1 \mathrm{~h}$ at $0{ }^{\circ} \mathrm{C}$ and then was allowed to reach room temperature. The mixture was concentrated under reduced pressure. After dilution with $\mathrm{Et}_{2} \mathrm{O}(50 \mathrm{~mL})$, the solution was washed with water $(3 \times 50 \mathrm{~mL})$, dried over $\mathrm{MgSO}_{4}$, and concentrated to give a residue that was purified by chromatography over silica gel (cyclohexane) to give 7 as light-yellow crystals (1.41 g, 97\% yield). $\mathrm{Mp} \mathrm{58-59}{ }^{\circ} \mathrm{C} .{ }^{1} \mathrm{H}$ NMR $\left(500 \mathrm{MHz}, \mathrm{CDCl}_{3}\right): \delta 3.69$ (s, 2H), 7.12 $(\mathrm{s}, 1 \mathrm{H}), 7.22\left(\mathrm{t}, 1 \mathrm{H},{ }^{3} \mathrm{~J}=7.4 \mathrm{~Hz}\right), 7.32\left(\mathrm{t}, 1 \mathrm{H},{ }^{3} J=7.5 \mathrm{~Hz}\right), 7.43$ $\left(\mathrm{d}, 1 \mathrm{H},{ }^{3} J=7.4 \mathrm{~Hz}\right), 7.48\left(\mathrm{~d}, 1 \mathrm{H},{ }^{3} J=7.3 \mathrm{~Hz}\right) . \mathrm{MS}(70 \mathrm{eV}, \mathrm{EI})$ $m / z(\mathrm{I} \%)=252\left(\mathrm{M}^{+\bullet}, 90\right), 250\left(\mathrm{M}^{+} \cdot 100\right), 171(90)$.

2-Tributylstannyl-4H-indeno[1,2-b]thiophene (8). Under a $\mathrm{N}_{2}$ atmosphere, a solution of $n$-BuLi 1.6 M in hexanes $(2.85 \mathrm{~mL}, 4.56$ $\mathrm{mmol})$ was added dropwise to a solution of 7 (1.10 g, $4.38 \mathrm{mmol})$ in anhydrous $\mathrm{Et}_{2} \mathrm{O}(125 \mathrm{~mL})$ cooled to $-78{ }^{\circ} \mathrm{C}$. After $0.5 \mathrm{~h}$ of stirring at this temperature, $\mathrm{Bu}_{3} \mathrm{SnCl} 96 \%(1.77 \mathrm{~mL}, 6.26 \mathrm{mmol})$ was added, and the reaction mixture was then allowed to warm slowly to room temperature. After dilution with $\mathrm{Et}_{2} \mathrm{O}(150 \mathrm{~mL})$, the mixture was washed successively with a saturated aqueous solution of $\mathrm{NH}_{4} \mathrm{Cl}(40 \mathrm{~mL})$ and brine $(2 \times 100 \mathrm{~mL})$. The organic phase was separated by decantation and concentrated under reduced pressure. The residue was diluted with EtOAc $(40 \mathrm{~mL})$, and a saturated aqueous solution of $\mathrm{NaF}(30 \mathrm{~mL})$ was added leading, after $20 \mathrm{~min}$ of stirring, to the precipitation of $\mathrm{Bu}_{3} \mathrm{SnF}$, which was separated by filtration. The filtered solution was washed with brine $(50 \mathrm{~mL})$, dried over $\mathrm{MgSO}_{4}$, and concentrated to dryness. The obtained oil $(2.03 \mathrm{~g})$ was sufficiently pure $(>90 \%)$ and hence was used in the next step without further purification. ${ }^{1} \mathrm{H}$ NMR (500 $\left.\mathrm{MHz}, \mathrm{CDCl}_{3}\right): \delta 0.91\left(\mathrm{t}, 9 \mathrm{H},{ }^{3} \mathrm{~J}=7.2 \mathrm{~Hz}\right), 1.08-1.25(\mathrm{~m}, 6 \mathrm{H})$, $1.34-1.39(\mathrm{~m}, 6 \mathrm{H}), 1.56-1.65(\mathrm{~m}, 6 \mathrm{H}), 3.68(\mathrm{~s}, 2 \mathrm{H}), 7.15(\mathrm{~s}, 1 \mathrm{H})$, $7.16\left(\mathrm{t}, 1 \mathrm{H},{ }^{3} \mathrm{~J}=7.4 \mathrm{~Hz}\right), 7.30\left(\mathrm{t}, 1 \mathrm{H},{ }^{3} \mathrm{~J}=7.4 \mathrm{~Hz}\right), 7.46(\mathrm{~d}, 1 \mathrm{H}$, $\left.{ }^{3} J=7.0 \mathrm{~Hz}\right), 7.48\left(\mathrm{~d}, 1 \mathrm{H},{ }^{3} J=7.4 \mathrm{~Hz}\right)$.

5,5'-Bis(4H-indeno $[1,2-b]$ thien-2-yl)-3,3'-bis(trimethylsilyl)2,2'-bithiophene (13). A mixture of 3,3'-bis(trimethylsilyl)-5,5'dibromo-2,2'-bithiophene $\mathbf{1 2}^{23 \mathrm{~h}}(1 \mathrm{~g}, 2.14 \mathrm{mmol})$ and stannyl derivative $8(2.53 \mathrm{~g}, 5.41 \mathrm{mmol})$ in the presence of $\mathrm{AsPh}_{3}(0.35 \mathrm{~g}$, $1.14 \mathrm{mmol})$ and $\mathrm{CuI}(0.10 \mathrm{~g}, 0.53 \mathrm{mmol})$ in anhydrous toluene (60
$\mathrm{mL}$ ) was degassed with $\mathrm{N}_{2}$ for 10 min before addition of $\mathrm{Pd}_{2} \mathrm{dba}_{3}$ $(015 \mathrm{~g}, 0.16 \mathrm{mmol})$. The reaction mixture was refluxed for $18 \mathrm{~h}$ under a $\mathrm{N}_{2}$ atmosphere. After concentration under reduced pressure, the residue was filtered on silica gel (eluent, $\mathrm{CH}_{2} \mathrm{Cl}_{2}$ ). Further purification was performed by a first column chromatography on silica gel with a mixture cyclohexane/ $\mathrm{CH}_{2} \mathrm{Cl}_{2}$ 9:1 as eluent and another one with cyclohexane as solvent $\left(R_{f}=0.37\right)$. Finally, a preparative thick layer chromatography on silica gel led to $13(0.43$ g, 31\% yield) as a yellow solid. Mp $193-194{ }^{\circ} \mathrm{C} .{ }^{1} \mathrm{H}$ NMR $(500$ $\left.\mathrm{MHz}, \mathrm{CDCl}_{3}\right): \delta 0.19(\mathrm{~s}, 18 \mathrm{H}), 3.71(\mathrm{~s}, 4 \mathrm{H}), 7.18(\mathrm{~s}, 2 \mathrm{H}), 7.21(\mathrm{t}$, $\left.2 \mathrm{H},{ }^{3} \mathrm{~J}=7.5 \mathrm{~Hz}\right), 7.23(\mathrm{~s}, 2 \mathrm{H}), 7.34\left(\mathrm{t}, 2 \mathrm{H},{ }^{3} \mathrm{~J}=7.3 \mathrm{~Hz}\right), 7.47(\mathrm{~d}$, $\left.2 \mathrm{H},{ }^{3} J=7.5 \mathrm{~Hz}\right), 7.49\left(\mathrm{~d}, 2 \mathrm{H},{ }^{3} J=7.5 \mathrm{~Hz}\right) .{ }^{13} \mathrm{C} \mathrm{NMR}(125 \mathrm{MHz}$, $\left.\mathrm{CDCl}_{3}\right): \delta 0.06,34.3,118.8,119.8,124.93,124.99,127.0,128.7$, $138.78,138.81,139.1,140.3,142.2,143.5,145.6,147.7 . \mathrm{MS}$ MALDI-TOF $650\left[\mathrm{M}^{+\bullet}\right]$. UV-vis $\left(\mathrm{CH}_{2} \mathrm{Cl}_{2}\right): \lambda_{\max }=379 \mathrm{~nm}$.

5,5'-Bis $(4 H$-indeno[1,2-b]thien-2-yl)-2,2'-bithiophene (4T). Miyaura-Suzuki Coupling. A solution of $\mathrm{Na}_{2} \mathrm{CO}_{3}(1.3 \mathrm{~g}, 12$ $\mathrm{mmol})$ in water $(10 \mathrm{~mL})$ and Aliquat $336(480 \mathrm{mg}, 1.2 \mathrm{mmol})$ was added to a mixture of diboronic ester $\mathbf{9}^{46}(500 \mathrm{mg}, 1.2 \mathrm{mmol})$ and iodo derivative $6(720 \mathrm{mg}, 2.4 \mathrm{mmol})$ in toluene $(15 \mathrm{~mL})$. This mixture was degassed with $\mathrm{N}_{2}$ for 15 min before addition of a catalytic amount of $\mathrm{Pd}\left(\mathrm{PPh}_{3}\right)_{4}(87 \mathrm{mg}, 75 \mu \mathrm{mol})$ and subsequent refluxing for $48 \mathrm{~h}$. The reaction mixture was then poured into $\mathrm{MeOH}$ $(100 \mathrm{~mL})$ leading to the formation of a brown precipitate, which was filtered and washed successively with toluene, an aqueous solution of $\mathrm{HCl} 5 \%$, water, hot $\mathrm{MeOH}(4 \times 75 \mathrm{~mL})$ and hot acetone $(3 \times 75 \mathrm{~mL})$. After drying, the brown precipitate was subjected to successive Soxhlet extractions with hexane $(5 \mathrm{~h})$, acetone $(15 \mathrm{~h})$, dichloromethane $(15 \mathrm{~h})$, toluene $(24 \mathrm{~h})$, and finally chlorobenzene $(2 \times 48 \mathrm{~h})$. The orange precipitate observed in the toluenic extract was filtered to give $75 \mathrm{mg}$ of compound $4 \mathrm{~T}$ as demonstrated by MALDI-TOF mass spectrometry and UV-vis spectroscopy. In addition the extracts obtained from chlorobenzene were concentrated and the resulting residue was triturated with acetone and filtered, washed with acetone and hexane, and dried to afford $120 \mathrm{mg}$ of compound 4T, accompanied by traces of 6T as observed by MALDI-TOF mass spectrometry ( $c a .32 \%$ of overall yield). Note that some amount of $\mathbf{2 T}$ as slightly yellow powder $(65 \mathrm{mg})$ resulting from homocoupling of compound $\mathbf{6}$ was obtained by evaporation of the dichloromethane extracts and further purification by dissolution in hot $\mathrm{CHCl}_{3}$ and precipitation using $\mathrm{EtOH}$.

Stille Coupling between 7 and 10. A mixture of 5,5'-bis(tributylstannyl)-2,2'-bithiophene $\mathbf{1 0}^{47}$ (1 $\left.\mathrm{g}, 1.34 \mathrm{mmol}\right)$ and bromo derivative $7(0.84 \mathrm{~g}, 3.35 \mathrm{mmol})$ in anhydrous toluene $(30 \mathrm{~mL})$ was degassed with $\mathrm{N}_{2}$ for 10 min before addition of $\mathrm{Pd}\left(\mathrm{PPh}_{3}\right)_{4}(150$ $\mathrm{mg}, 0.13 \mathrm{mmol})$. The reaction mixture was refluxed for $16 \mathrm{~h}$ under a $\mathrm{N}_{2}$ atmosphere. At room temperature, the resulting orange precipitate was filtered, successively washed with toluene and pentane and dried to give $0.53 \mathrm{~g}$ of orange powder. The same sequence of Soxhlet extractions as Miyaura-Suzuki coupling was carried out on the orange powder leading to $80 \mathrm{mg}$ of $\mathbf{4 T}$ obtained from the precipitate of the toluenic extracts while the extracts of chlorobenzene gave $220 \mathrm{mg}$ of $\mathbf{4 T}$, accompanied by traces of $\mathbf{6 T}$ as observed by MALDI-TOF mass spectrometry ( $c a$. $44 \%$ of overall yield).

Stille Coupling between 8 and 11. A mixture of 5,5'-dibromo2,2'-bithiophene $\mathbf{1 1}^{48}(0.27 \mathrm{~g}, 0.83 \mathrm{mmol})$ and stannyl derivative $\mathbf{8}$ $(1.02 \mathrm{~g}, 2.21 \mathrm{mmol})$ in anhydrous toluene $(30 \mathrm{~mL})$ was degassed with $\mathrm{N}_{2}$ for $10 \mathrm{~min}$ before addition of $\mathrm{Pd}\left(\mathrm{PPh}_{3}\right)_{4}(100 \mathrm{mg}, 0.09$ mmol). The reaction mixture was refluxed for $21 \mathrm{~h}$ under a $\mathrm{N}_{2}$ atmosphere. At room temperature, the resulting orange precipitate was filtered, successively washed with toluene and pentane and dried to give $0.35 \mathrm{~g}$ of orange powder. The same sequence of Soxhlet extractions as Miyaura-Suzuki coupling was carried out leading to $50 \mathrm{mg}$ of $\mathbf{4 T}$ obtained from the precipitate of the toluenic extracts while the extracts of chlorobenzene gave $150 \mathrm{mg}$ of 4T, accompanied by traces of $\mathbf{6 T}$ as observed by MALDI-TOF mass spectrometry ( $c a .48 \%$ of overall yield). 
Elimination of Trimethylsilyl Groups of 13. A solution of $n-\mathrm{Bu}_{4} \mathrm{NF} 1 \mathrm{M}$ in THF $(1 \mathrm{~mL})$ was added to a solution of $\mathbf{1 3}$ (100 $\mathrm{mg}, 0.15 \mathrm{mmol})$ in pyridine $(10 \mathrm{~mL})$ and the reaction mixture was stirred at $20{ }^{\circ} \mathrm{C}$ for $20 \mathrm{~h}$. The resulting precipitate was filtered, washed successively with water $(3 \times 50 \mathrm{~mL})$, acetone $(3 \times 50$ $\mathrm{mL})$ and $\mathrm{Et}_{2} \mathrm{O}(2 \times 50 \mathrm{~mL})$ and dried affording $4 \mathrm{~T}(40 \mathrm{mg}, 51 \%$ yield).

4T: $\mathrm{Mp} 356{ }^{\circ} \mathrm{C}$. ${ }^{1} \mathrm{H}$ NMR analysis was prevented due to the lack of solubility of $\mathbf{4 T}$ in $\mathrm{CDCl}_{3}$, pyridine- $\mathrm{d}_{5}, \mathrm{THF}-\mathrm{d}_{8}, \mathrm{DMSO}-\mathrm{d}_{6}$, DMF- $\mathrm{d}_{7}$, benzene- $\mathrm{d}_{6}$ and chlorobenzene- $\mathrm{d}_{5}$ at $20^{\circ} \mathrm{C}$. However, one singlet was observed for the two methylene bridges at $3.72 \mathrm{ppm}$ in hot $\mathrm{CDCl}_{3}\left(55^{\circ} \mathrm{C}\right)$ or at $3.80 \mathrm{ppm}$ in hot DMSO-d ${ }_{6}\left(90^{\circ} \mathrm{C}\right.$ ) (see Supporting Information). MS MALDI-TOF $506\left[\mathrm{M}^{+\bullet}\right]$. ESI ${ }^{+}$ HRMS: cald for $\mathrm{C}_{30} \mathrm{H}_{18} \mathrm{~S}_{4}$ 506.02914; found 506.0293. UV-vis $\left(\mathrm{CH}_{2} \mathrm{Cl}_{2}\right): \lambda_{\max }=442 \mathrm{~nm}$.

2T: $\mathrm{Mp} 124-125{ }^{\circ} \mathrm{C}$. ${ }^{1} \mathrm{H}$ NMR $\left(500 \mathrm{MHz}, \mathrm{CDCl}_{3}\right): \delta 3.72$ (s, 4H), $7.21\left(\mathrm{t}, 2 \mathrm{H},{ }^{3} J=7.5 \mathrm{~Hz}\right), 7.25(\mathrm{~s}, 2 \mathrm{H}), 7.33\left(\mathrm{t}, 2 \mathrm{H},{ }^{3} \mathrm{~J}=\right.$ $7.5 \mathrm{~Hz}), 7.47\left(\mathrm{~d}, 2 \mathrm{H},{ }^{3} \mathrm{~J}=7.5 \mathrm{~Hz}\right), 7.49\left(\mathrm{~d}, 2 \mathrm{H},{ }^{3} \mathrm{~J}=7.5 \mathrm{~Hz}\right) .{ }^{13} \mathrm{C}$ NMR: 2T was too insoluble in $\mathrm{CDCl}_{3}$, pyridine- $\mathrm{d}_{5}$ and DMSO- $\mathrm{d}_{6}$ to obtain a ${ }^{13} \mathrm{C}$ NMR spectrum. MS MALDI-TOF $342\left[\mathrm{M}^{+} \cdot{ }^{\circ}\right.$. ESI ${ }^{+}$ HRMS: cald for $\mathrm{C}_{22} \mathrm{H}_{14} \mathrm{~S}_{2} 342.05369$; found 342.0535. UV-vis $\left(\mathrm{CH}_{2} \mathrm{Cl}_{2}\right): \lambda_{\max }=380 \mathrm{~nm}(\mathrm{sh}), 397 \mathrm{~nm}, 417 \mathrm{~nm}(\mathrm{sh})$.

4,4-Dioctyl-4H-indeno[1,2-b]thiophene (14). Potassium hydroxide $(2.5 \mathrm{~g})$ was added to a mixture of $\mathbf{5}(2.4 \mathrm{~g}, 13.9 \mathrm{mmol})$, 1-bromooctane $(5.97 \mathrm{~g}, 11 \mathrm{mmol})$ and potassium iodide $(70 \mathrm{mg}$, $0.4 \mathrm{mmol})$ in DMSO $(60 \mathrm{~mL})$ cooled to $0{ }^{\circ} \mathrm{C}$. The resulting solution was allowed to reach room temperature overnight. Water $(100 \mathrm{~mL})$ was slowly poured into the reaction mixture previously cooled to $0{ }^{\circ} \mathrm{C}$. The mixture was extracted with $\mathrm{Et}_{2} \mathrm{O}(2 \times 80 \mathrm{~mL})$, and the combined organic extracts were washed with water, brine, an aqueous saturated solution of $\mathrm{NH}_{4} \mathrm{Cl}$, dried over $\mathrm{MgSO}_{4}$ and concentrated under vacuum. The residual 1-bromooctane was distilled using a Kugelrohr apparatus. The resulting brown oil was purified by chromatography of silica gel (eluent: Petroleum Ether) to give 14 as a colorless oil (3.4 g, 60\% yield). ${ }^{1} \mathrm{H}$ NMR (500 $\left.\mathrm{MHz}, \mathrm{CDCl}_{3}\right): \delta 0.72-0.85(\mathrm{~m}, 4 \mathrm{H}), 0.84\left(\mathrm{t}, 6 \mathrm{H},{ }^{3} J=7.3 \mathrm{~Hz}\right)$, $1.06-1.25(\mathrm{~m}, 20 \mathrm{H}), 1.84\left(\mathrm{dt}, 2 \mathrm{H},{ }^{2} \mathrm{~J}=13.0 \mathrm{~Hz},{ }^{3} \mathrm{~J}=4.8 \mathrm{~Hz}\right)$, $1.94\left(\mathrm{dt}, 2 \mathrm{H},{ }^{2} J=13.0 \mathrm{~Hz},{ }^{3} \mathrm{~J}=4.8 \mathrm{~Hz}\right), 6.97\left(\mathrm{~d}, 1 \mathrm{H},{ }^{3} \mathrm{~J}=4.8\right.$ $\mathrm{Hz}), 7.18\left(\mathrm{dt}, 1 \mathrm{H},{ }^{3} J=7.4 \mathrm{~Hz},{ }^{4} J=1 \mathrm{~Hz}\right), 7.24-7.30(\mathrm{~m}, 3 \mathrm{H})$, $7.40\left(\mathrm{~d}, 1 \mathrm{H},{ }^{3} J=7.4 \mathrm{~Hz}\right) .{ }^{13} \mathrm{C} \mathrm{NMR}\left(125 \mathrm{MHz}, \mathrm{CDCl}_{3}\right): \delta 14.1$, 22.6, 24.1, 29.2, 29.3, 30.1, 31.8, 39.0, 53.8, 118.6, 121.5, 122.6, $124.9,126.7,127.1,138.2,141.1,153.9,155.4$. MS (70 eV, EI) $\mathrm{m} / \mathrm{z}(\mathrm{I} \%)=396\left(\mathrm{M}^{+}{ }^{+}, 100 \%\right)$. Anal. Calcd for $\mathrm{C}_{27} \mathrm{H}_{40} \mathrm{~S}: \mathrm{C}, 81.74$; H, 10.16. Found: C, 81.71; H, 10.42 .

2-Iodo-4,4-dioctyl-4H-indeno[1,2- $b$ ] thiophene (15). A solution of $N$-iodosuccinimide $(580 \mathrm{mg}, 2.6 \mathrm{mmol})$ in DMF $(30 \mathrm{~mL})$ was added dropwise to a solution of $\mathbf{1 4}(1 \mathrm{~g}, 2.5 \mathrm{mmol})$ in DMF (20 $\mathrm{mL}$ ) cooled to $0{ }^{\circ} \mathrm{C}$ and protected from the daylight. The resulting solution was stirred for $1 \mathrm{~h}$ at $0{ }^{\circ} \mathrm{C}$, and then allowed to reach room temperature. Water $(400 \mathrm{~mL})$ was added and the resulting mixture was extracted with $\mathrm{CH}_{2} \mathrm{Cl}_{2}(4 \times 100 \mathrm{~mL})$. The organic layers were gathered, washed with water $(4 \times 60 \mathrm{~mL})$, dried over magnesium sulfate and concentrated. A chromatography on silica gel (eluent: cyclohexane) afforded $\mathbf{1 5}$ (1.2 g, 92\% yield) as a colorless oil. ${ }^{1} \mathrm{H}$ NMR $\left(500 \mathrm{MHz}, \mathrm{CDCl}_{3}\right): \delta 0.66-0.77(\mathrm{~m}, 4 \mathrm{H})$, $0.84\left(\mathrm{t}, 6 \mathrm{H},{ }^{3} \mathrm{~J}=7.2 \mathrm{~Hz}\right), 1.05-1.32(\mathrm{~m}, 20 \mathrm{H}), 1.76-1.91(\mathrm{~m}, 4$ $\mathrm{H}), 7.13(\mathrm{~s}, 1 \mathrm{H}), 7.19\left(\mathrm{t}, 1 \mathrm{H},{ }^{3} J=7.5 \mathrm{~Hz}\right), 7.24\left(\mathrm{t}, 1 \mathrm{H},{ }^{3} J=7.5\right.$ $\mathrm{Hz}), 7.25\left(\mathrm{~d}, 1 \mathrm{H},{ }^{3} \mathrm{~J}=7.5 \mathrm{~Hz}\right), 7.33\left(\mathrm{~d}, 1 \mathrm{H},{ }^{3} \mathrm{~J}=7.5 \mathrm{~Hz}\right) .{ }^{13} \mathrm{C}$ NMR $\left(125 \mathrm{MHz}, \mathrm{CDCl}_{3}\right): \delta 14.3,22.8,24.2,29.4,29.4,30.1,31.9$, 39.0, 54.5, $74.3(\mathrm{C}-\mathrm{I}), 118.9,122.8,125.5,127.0,131.2,137.8$, 146.4, 153.0, 156.0. MS $(70 \mathrm{eV}, \mathrm{EI}) \mathrm{m} / \mathrm{z}(\mathrm{I} \%)=522\left(\mathrm{M} \cdot{ }^{+}, 100\right)$.

2-Trimethylstannyl-4,4-dioctyl-4H-indeno[1,2-b]thiophene (16). A solution of $n$-BuLi $2.5 \mathrm{M}$ in hexanes $(1.75 \mathrm{~mL})$ was added dropwise to a solution of $\mathbf{1 5}(2.1 \mathrm{~g}, 4.02 \mathrm{mmol})$ in anhydrous $\mathrm{Et}_{2} \mathrm{O}(50 \mathrm{~mL})$ under inert atmosphere at $-70^{\circ} \mathrm{C}$. The reaction mixture was then allowed to reach $0{ }^{\circ} \mathrm{C}$ and then cooled to $-50{ }^{\circ} \mathrm{C}$ before addition of a solution of trimethyltin chloride $(920 \mathrm{mg}, 4.62 \mathrm{mmol})$ in anhydrous $\mathrm{Et}_{2} \mathrm{O}(10 \mathrm{~mL})$. The reaction mixture was allowed to reach room temperature and was diluted with Petroleum Ether $(100 \mathrm{~mL})$.
A saturated aqueous solution of $\mathrm{NH}_{4} \mathrm{Cl}$ was added to the mixture and, after vigorous stirring for $0.5 \mathrm{~h}$, the organic phase was separated by decantation, dried over $\mathrm{MgSO}_{4}$ and concentrated. The viscous oil was dissolved in EtOAc $(50 \mathrm{~mL})$ and was vigorously stirred for $0.5 \mathrm{~h}$ after addition of a saturated aqueous solution of $\mathrm{NaF}$ to get rid of the unreacted trimethyltin chloride. The resulting precipitate was filtered over celite which was rinsed with EtOAc. The filtrated solution was washed with brine $(50 \mathrm{~mL})$, water $(50$ $\mathrm{mL}$ ), dried over $\mathrm{MgSO}_{4}$ and concentrated. The resulting oil (1.80 g) consisted of a mixture of $c a$. $80 \%$ of $\mathbf{1 6}$ and $c a$. $20 \%$ of $\mathbf{1 4}$ as determined by ${ }^{1} \mathrm{H}$ NMR. This crude product was used in the next step without further purification.

5,5'-Bis(4,4-dioctyl-4H-indeno[1,2-b]thien-2-yl)-2,2'-bithiophene (Oct-4T). Miyaura-Suzuki Coupling between 15 and 9. A solution of $\mathrm{Na}_{2} \mathrm{CO}_{3}(0.65 \mathrm{~g}, 6 \mathrm{mmol})$ in water $(5 \mathrm{~mL})$ was added to a mixture of boronic ester $\mathbf{9}^{46}(0.25 \mathrm{~g}, 0.6 \mathrm{mmol})$, compound 15 (630 mg, $1.2 \mathrm{mmol})$ and Aliquat $336(240 \mathrm{mg}, 0.6$ $\mathrm{mmol})$ in toluene $(10 \mathrm{~mL})$. This mixture was degassed with $\mathrm{N}_{2}$ for $0.5 \mathrm{~h}$ before addition of $\mathrm{Pd}\left(\mathrm{PPh}_{3}\right)_{4}(50 \mathrm{mg}, 45 \mu \mathrm{mol})$ and subsequent refluxing for $65 \mathrm{~h}$ under a $\mathrm{N}_{2}$ atmosphere. Water $(100 \mathrm{~mL})$ was added and the reaction mixture was extracted with Petroleum Ether $(3 \times 100 \mathrm{~mL})$. The organic phases were gathered, washed with an aqueous solution of $\mathrm{HCl} 1 \mathrm{M}(100 \mathrm{~mL})$, brine $(100 \mathrm{~mL})$, dried over $\mathrm{MgSO}_{4}$ and concentrated under reduced pressure. Chromatography on silica gel (eluent: Petroleum Ether) led to a fraction corresponding to Oct-2T as a yellow oil $\left(\mathrm{R}_{\mathrm{f}}=0.62,80 \mathrm{mg}, 27 \%\right.$ yield) and to a fraction corresponding to Oct-4T as an orange-red powder $\left(\mathrm{R}_{\mathrm{f}}=0.49,140 \mathrm{mg}, 24 \%\right.$ yield $)$.

Stille Coupling between 16 and 11. $\mathrm{Pd}\left(\mathrm{PPh}_{3}\right)_{4}(120 \mathrm{mg}, 0.11$ mmol) was added to a $\mathrm{N}_{2}$ degassed solution of $\mathbf{1 6}(1.80 \mathrm{~g}, 80 \%$ pure, $2.6 \mathrm{mmol}$ ) and dibromobithiophene $\mathbf{1 1}^{48}$ (360 $\mathrm{mg}, 1.1 \mathrm{mmol}$ ) in toluene $(50 \mathrm{~mL})$. The reaction mixture was refluxed for $24 \mathrm{~h}$, and then water $(60 \mathrm{~mL})$ was added at room temperature. The mixture was diluted with Petroleum Ether $(50 \mathrm{~mL})$, washed with brine $(50 \mathrm{~mL})$, dried over $\mathrm{MgSO}_{4}$ and concentrated. The viscous red oil was purified by chromatography on silica gel (eluent: Petroleum Ether) to give Oct-4T as an orange-red solid $\left(\mathrm{R}_{\mathrm{f}}=0.49\right.$, $690 \mathrm{mg}, 66 \%$ yield $)$. Compound Oct-6T $\left(\mathrm{R}_{\mathrm{f}}=0.27,120 \mathrm{mg}, 16 \%\right.$ yield) was also isolated as bright red powder.

Oct-2T: ${ }^{1} \mathrm{H}$ NMR (500 MHz, $\mathrm{CDCl}_{3}$ ): $\delta 0.71-098$ (m, 8H), 0.82 $\left(\mathrm{t}, 12 \mathrm{H},{ }^{3} \mathrm{~J}=7.2 \mathrm{~Hz}\right), 1.06-1.30(\mathrm{~m}, 40 \mathrm{H}), 1.85(\mathrm{~m}, 4 \mathrm{H}), 1.94$ $(\mathrm{m}, 4 \mathrm{H}), 7.09(\mathrm{~s}, 2 \mathrm{H}), 7.18\left(\mathrm{t}, 2 \mathrm{H},{ }^{3} \mathrm{~J}=7.5 \mathrm{~Hz}\right), 7.26(\mathrm{~m}, 4 \mathrm{H})$, $7.36\left(\mathrm{~d}, 2 \mathrm{H},{ }^{3} \mathrm{~J}=7.5 \mathrm{~Hz}\right)$. MS MALDI-TOF $790\left[\mathrm{M}^{+\bullet}\right]$. UV-vis $\left(\mathrm{CH}_{2} \mathrm{Cl}_{2}\right): \lambda_{\max }=391 \mathrm{~nm}(\mathrm{sh}), 408 \mathrm{~nm}, 427 \mathrm{~nm}(\mathrm{sh})$.

Oct-4T: Mp 101-102 ${ }^{\circ} \mathrm{C} .{ }^{1} \mathrm{H}$ NMR $\left(500 \mathrm{MHz}, \mathrm{CDCl}_{3}\right): \delta$ $0.75-0.92(\mathrm{~m}, 8 \mathrm{H}), 0.83\left(\mathrm{t}, 12 \mathrm{H},{ }^{3} \mathrm{~J}=7.2 \mathrm{~Hz}\right), 1.11-1.26$ $(\mathrm{m}, 40 \mathrm{H}), 1.85\left(\mathrm{dt}, 4 \mathrm{H},{ }^{2} J=13.0 \mathrm{~Hz},{ }^{3} \mathrm{~J}=4.6 \mathrm{~Hz}\right), 1.94(\mathrm{dt}, 4 \mathrm{H}$, $\left.{ }^{2} J=13.0 \mathrm{~Hz},{ }^{3} J=4.6 \mathrm{~Hz}\right), 7.04-7.14(\mathrm{~m}, 6 \mathrm{H}), 7.20\left(\mathrm{t}, 2 \mathrm{H},{ }^{3} J=\right.$ $7.5 \mathrm{~Hz}), 7.25-7.30(\mathrm{~m}, 4 \mathrm{H}), 7.39\left(\mathrm{~d}, 2 \mathrm{H},{ }^{3} \mathrm{~J}=7.5 \mathrm{~Hz}\right) .{ }^{13} \mathrm{C} \mathrm{NMR}$ $\left(125 \mathrm{MHz}, \mathrm{CDCl}_{3}\right): \delta 14.1,22.7,24.2,29.32,29.35,30.1,31.8$, 39.0, 54.4, 118.2, 118.7, 122.5, 123.7, 124.2, 125.3, 126.9, 135.5, 137.4, 138.0, 139.1, 140.4, 153.4, 156.1. MS MALDI-TOF 954 $\left[\mathrm{M}^{+\bullet}\right]$. UV-vis $\left(\mathrm{CH}_{2} \mathrm{Cl}_{2}\right): \lambda_{\max }=450 \mathrm{~nm}$. Anal. Calcd for $\mathrm{C}_{62} \mathrm{H}_{82} \mathrm{~S}_{4}$ : C, 77.93; H, 8.65. Found: C, 77.72; H, 8.72.

Oct-6T: Mp 147-148 ${ }^{\circ} \mathrm{C}$. ${ }^{1} \mathrm{H}$ NMR $\left(500 \mathrm{MHz}, \mathrm{CDCl}_{3}\right): \delta$ $0.73-0.93(\mathrm{~m}, 8 \mathrm{H}), 0.83\left(\mathrm{t}, 12 \mathrm{H},{ }^{3} \mathrm{~J}=7.2 \mathrm{~Hz}\right), 1.08-1.26(\mathrm{~m}$, $40 \mathrm{H}), 1.86\left(\mathrm{dt}, 4 \mathrm{H},{ }^{2} J=13.0 \mathrm{~Hz},{ }^{3} J=4.6 \mathrm{~Hz}\right), 1.94\left(\mathrm{dt}, 4 \mathrm{H},{ }^{2} J=\right.$ $\left.13.0 \mathrm{~Hz},{ }^{3} \mathrm{~J}=4.6 \mathrm{~Hz}\right), 7.04-7.15(\mathrm{~m}, 10 \mathrm{H}), 7.20\left(\mathrm{t}, 2 \mathrm{H},{ }^{3} \mathrm{~J}=7.5\right.$ $\mathrm{Hz}), 7.25-7.30(\mathrm{~m}, 4 \mathrm{H}), 7.39\left(\mathrm{~d}, 2 \mathrm{H},{ }^{3} \mathrm{~J}=7.5 \mathrm{~Hz}\right) .{ }^{13} \mathrm{C}$ NMR $(125$ $\left.\mathrm{MHz}, \mathrm{CDCl}_{3}\right): \delta 14.2,22.7,24.2,29.3,29.4,30.1,31.9,39.0,54.4$, $118.2,118.7,122.6,123.7,124.3,124.5,124.5,125.3,127.0,135.3$, 135.9, 136.2, 137.6, 138.0, 139.1, 140.4, 153.5, 156.1. ESI ${ }^{+}$HRMS: calcd for $\mathrm{C}_{62} \mathrm{H}_{82} \mathrm{~S}_{4}$ 1118.50538; found 1118.5036. UV-vis $\left(\mathrm{CH}_{2} \mathrm{Cl}_{2}\right): \lambda_{\max }=470 \mathrm{~nm}$.

2-Trimethylstannyl-4,4-di-p-tolyl-4H-indeno[1,2- $b]$ thiophene (19). A solution of $n$-BuLi $1.6 \mathrm{M}$ in hexanes $(1.2 \mathrm{~mL}, 1.92 \mathrm{mmol})$ was added dropwise to a solution of $18(0.77 \mathrm{~g}, 1.78 \mathrm{mmol})$ in anhydrous THF $(35 \mathrm{~mL})$ cooled to $-75{ }^{\circ} \mathrm{C}$ under an inert atmosphere. After $0.5 \mathrm{~h}$ of stirring at this temperature, a solution 
of $\mathrm{Me}_{3} \mathrm{SnCl} 1 \mathrm{M}$ in THF $(2.2 \mathrm{~mL}, 2.2 \mathrm{mmol})$ was added to the reaction mixture, which was then allowed to warm to room temperature and stirred for $12 \mathrm{~h}$. After dilution with $\mathrm{Et}_{2} \mathrm{O}(150 \mathrm{~mL})$, the reaction mixture was washed with a saturated aqueous solution of $\mathrm{NH}_{4} \mathrm{Cl}(100 \mathrm{~mL})$ and concentrated under reduced pressure. The residue was diluted with EtOAc $(30 \mathrm{~mL})$ and a saturated aqueous solution of $\mathrm{NaF}(25 \mathrm{~mL})$ was added. This mixture was stirred for $20 \mathrm{~min}$ and filtered on celite, and the filtered solution was washed with a saturated aqueous solution of $\mathrm{NaCl}(15 \mathrm{~mL})$, dried over $\mathrm{MgSO}_{4}$, and concentrated to dryness. The resulting oil $(0.77 \mathrm{~g})$ consisted of a mixture of ca. $70 \%$ of $\mathbf{1 9}$ and ca. $30 \%$ of $\mathbf{1 7}$ as determined by ${ }^{1} \mathrm{H}$ NMR. This crude product was used in the next step without further purification.

5,5'-Bis(4,4-di- $p$-tolyl-4H-indeno[1,2-b]thien-2-yl)-2,2'-bithiophene (Tol-4T). A mixture of 5,5'-dibromo-2,2'-bithiophene 11 $(0.19,0.59 \mathrm{mmol})$ and stannyl derivative $19(0.77 \mathrm{~g}, 80 \%$ pure, $1.20 \mathrm{mmol})$ in anhydrous toluene $(30 \mathrm{~mL})$ was nitrogen degassed for $15 \mathrm{~min}$ before addition of $\mathrm{Pd}\left(\mathrm{PPh}_{3}\right)_{4}(0.17 \mathrm{~g}, 0.15 \mathrm{mmol})$. The reaction mixture was refluxed for $21 \mathrm{~h}$ under an inert atmosphere. After concentration under reduced pressure, the resulting residue was subjected to two successive column chromatographies on silica gel (eluent, cyclohexane/ $\mathrm{CH}_{2} \mathrm{Cl}_{2}$ 90:10) to give a orange-red solid, which was further recrystallized from a mixture of $\mathrm{CH}_{2} \mathrm{Cl}_{2}$ and EtOH leading to Tol-4T as an orange-red crystalline powder $(0.27$ g, 53\% yield). Mp 212-214 ${ }^{\circ} \mathrm{C} .{ }^{1} \mathrm{H}$ NMR (500 MHz, $\left.\mathrm{CDCl}_{3}\right): \delta$ $2.30(\mathrm{~s}, 12 \mathrm{H}), 7.03\left(\mathrm{~d}, 2 \mathrm{H},{ }^{3} \mathrm{~J}=4.1 \mathrm{~Hz}\right), 7.05\left(\mathrm{~d}, 8 \mathrm{H},{ }^{3} \mathrm{~J}=8.2\right.$ $\mathrm{Hz}), 7.07\left(\mathrm{~d}, 2 \mathrm{H},{ }^{3} \mathrm{~J}=4.1 \mathrm{~Hz}\right), 7.08(\mathrm{~s}, 2 \mathrm{H}), 7.13\left(\mathrm{~d}, 8 \mathrm{H},{ }^{3} \mathrm{~J}=8.3\right.$
$\mathrm{Hz}), 7.17\left(\mathrm{dt}, 2 \mathrm{H},{ }^{3} J=7.6 \mathrm{~Hz},{ }^{4} J=1.1 \mathrm{~Hz}\right), 7.28\left(\mathrm{dt}, 2 \mathrm{H},{ }^{3} J=7.5\right.$ $\left.\mathrm{Hz},{ }^{4} \mathrm{~J}=0.8 \mathrm{~Hz}\right), 7.34\left(\mathrm{~d}, 2 \mathrm{H},{ }^{3} \mathrm{~J}=7.5 \mathrm{~Hz}\right), 7.42\left(\mathrm{~d}, 2 \mathrm{H},{ }^{3} \mathrm{~J}=7.4\right.$ $\mathrm{Hz}){ }^{13} \mathrm{C}$ NMR $\left(125 \mathrm{MHz}, \mathrm{CDCl}_{3}\right): \delta 21.0,63.2,119.4,119.5,124.0$, $124.2,124.3,124.5,125.09,126.14,127.6,127.8,129.1,135.7$, $136.5,136.96,137.01,140.0,140.1,141.6,153.3,156.4$. MS (70 $\mathrm{eV}, \mathrm{EI}) \mathrm{m} / \mathrm{z}(\mathrm{I} \%)=866\left(\mathrm{M}^{+}, \mathrm{100}\right), 433(80) . \mathrm{ESI}^{+} \mathrm{HRMS}$ : calcd for $\mathrm{C}_{58} \mathrm{H}_{42} \mathrm{~S}_{4}$ 866.21694; found 866.2168. UV-vis $\left(\mathrm{CH}_{2} \mathrm{Cl}_{2}\right)$ : $\lambda_{\text {max }}$ $=452 \mathrm{~nm}$.

Acknowledgment. The Conseil Général of Maine and Loire and the city of Angers are acknowledged for providing a Ph.D. grant for L.P. and Y.N., respectively. The authors thank the Service Central d'Analyses Spectroscopiques de l'Université d'Angers for the characterization of organic compounds.

Supporting Information Available: Synthetic procedures for compounds $\mathbf{2 - 5}, \mathbf{1 7}$, and 18; thermal stability data for 4T, Oct-4T, and Tol-4T; MALDI-TOF mass spectra of 4T; cyclic voltammograms of 2T and Tol-4T; absorption and emission spectra of Tol-4T; emission spectrum of a film of Oct-4T; transfer characteristic and $\log \left(I_{\mathrm{DS}}\right)$ vs $\mathrm{V}_{\mathrm{G}}$ plot of an OFET based on $4 \mathrm{~T} ;{ }^{1} \mathrm{H}$ and ${ }^{13} \mathrm{C}$ NMR spectra of new compounds; and crystallographic data for Tol-4T presented in CIF format. This material is available free of charge via the Internet at http://pubs.acs.org.

JO802028N 